\title{
Amfitiyatro, Gösteri ve İktidar Oyunları
}

\author{
Fidan Terzioğlu \\ Doktora Öğrencisi \\ Galatasaray Üniversitesi Medya ve İletişim Çalışmaları Bölümü \\ fidanterzioglu@gmail.com
}

\section{Öz}

Bu makale, toplu anlatıların seyir mekânı olarak amfitiyatronun tarih boyunca geçirdiği dönüşümleri, "gösteri" kavramı ve bu kavramla etkileşen iktidar ilişkileri bağlamında incelemektedir. Bu amaçla, amfitiyatronun oluşumu ve dönüşümleri; bu mekânın her dönemde yüklendiği sosyal, kültürel ve siyasal işlevler bakımından ortaya konularak yorumlanmıştır. Her dönemdeki iktidar ilişkilerinin amfitiyatro mekânını nasıl dönüştürdüğü ve bu mekândaki gösterinin iktidar ilişkilerini nasıl etkilediği tartışmaya açılmıştır. Eleştirel teori geleneğinde "gösteriselleşme" olarak nitelenen, kapitalist toplumdaki her şeyin tüketime yönelik, içeriksiz bir imgeye dönüşmesi olgusunun kökenleri ve dinamikleri incelenmiştir. Insanlık tarihinin en eski sanatlarından biri olan seyirlik anlatı sanatının, yüzyıllar boyunca gelişerek, derinleşerek, kişilerin özümsediği, içselleştirdiği bir dili nasıl oluşturduğu araştııımıştır. Bütün bunlardan yola çıkılarak, "gösteriselleşme" olgusunun ötesine geçebilme imkânlarının ne yönde olabileceği işaret edilmiştir.

Anahtar sözcükler: gösteri, gösteriselleşme, kentsel mekân, amfitiyatro, iktidar, tiyatro, sinema 


\section{Amphitheatre, Spectacle and Plays of Power}

\section{Abstract}

This paper examines the transformations of the amphitheatre as the site of collective narratives, within the context of the "spectacle" and its interaction with complex relations of power. For this purpose, the emergence and the transfigurations of the amphitheatre are traced through their various phases and interpreted in terms of their social, cultural and political functions. The ways in which the spectacle in the amphitheatre interacts with the power relations in the society is investigated through their multivarious faces. This study examines the roots and dynamics of the "spectacle" as a symptom of the capitalist society in which everything is reduced into an image of meaningless commodity. This is an investigation of the process in which the language of the narrative spectacle is internalized through its complex evolutionary adventure within several centuries of power relations. In conclusion of this investigation, we attempt to point towards a direction that may lead to ways in which to transcend the black hole of the "spectacle" may be possible.

Keywords: Spectacle, the society of spectacle, urban space, amphitheatre, power, theatre, cinema

\section{L'Amphithéâtre, le spectacle et les jeux de pouvoir}

\section{Résumé}

Cet article analyse la transformation de l'amphithéâtre comme un espace de contemplation des narratifs anonymes, dans le contexte du concept de "spectacle" et des relations de pouvoir en interaction avec celui-ci. Pour cet objectif, on a essayé de préciser et d'interpréter la construction et les transformations des étapes de la treansformation de l'amphithéâtre dans ses fonctions sociales, culturelles et politiques. On a essayé de discuter comment les relations de pouvoir de différentes é périodesde l'histoire ont transformé l'amphithéâtre comme espace et comment le spec- tacle dans ce même espace a influencé les relations du pouvoir. On a taché d'examiner les origines et les dynamiques en se basant sur l'idée que la transformation de tout ce qui existe dans la société capitaliste a un image sans consistance; d'où le fait qu'on nomme comme "spectacularisation" dans la tradition de la théorie critique. On a recherché comment, étant un des plus anciens de l'histoire humaine l'art de narrative spectaculaire a réussi pendant des siècles à construire une langue ap-propriée et assimilée Avec ces points de repère, on a attirél'attention sur l'orientation possible d'aller au-delà du fait de "spectacularisation".

Mot clés: Spectacle, société du spectacle, espace urbain, amphithéâtre, pouvoir, théâtre, cinéma

\section{Gösteri ve "Gösteriselleşme"}

"Gösteri" kavramı, 20. yüzyılda oluşturulan toplum ve kültür eleştirilerinde anahtar konumda yer alır. Ancak bu kavram, birbirinden öylesine farklı anlam ve bağlamlar içinde kullanılmıştır ki, "gösteri" dediğimizde neyi işaret ettiğimizi önce biraz belirlememiz gerekir.

Gösteri, en temel anlamıyla, bir topluluk veya kişinin izlemesi veya katılması için sergilenen bir olguyu işaret eder. Biz bu yazıda "gösteri" dediğimizde, bir topluluğun izlemesi için sergilenen anlatısal bir seyirlikten söz ediyor olacağız.

Ancak eleştirel teoride, Marksizm ve Frankfurt Okulu çizgisinde oluşan ve Guy Debord tarafından vurgulanan "gösteriselleşme" kavramı ayrı bir yer tutar. Debord'un işaret ettiği bu gösteriselleşmede, "gösteri" görünür bir olgu değil, her an deneyimlenen, ancak görünmeyen bir yaşama halidir. Bu yaşama halinde, her şey değiş-tokuş edilebilir imgelere indirgenmiştir. İmgelerin değiş-tokuş edilebilirlik değeri öylesine baskın hale gelmiştir ki, bunun ötesinde anlamlı ve sahici bir insan ilişkisi kurma olasıı̆ı kalmamış gibidir. Bu anlamıyla "gösteri", anlam olasılığını yutup yok eden bir kör nokta, bir kara deliktir (Debord, 1994). Debord'un bu tarifi, iki dünya savaşından sonra oluşan biçimiyle tüketim kültürünün metaforik bir teşhisidir.

Bu yazıda, gösteriselleşme durumunun içerdiği ilişkileri anlayabilmek üzere, anlatısal seyirliklerin tarihsel mekânına, amfitiyatroya doğru bir yolculuk yapacağız. Amfitiyatronun tarih boyunca geçirdiği dönüşümü incelerken, bu dönüşümün yansıttığı kültürel ve siyasî ilişkileri tartışacağız. Son bölümde ise, gösteriselleşme olgusunun ötesine geçmenin imkânlarını araştıracağız.

\section{Amfitiyatro: Seyir Mekânı}

Amfitiyatronun etimolojik kökenine bakarak ișe bașlayalım. Yunanca amphi (çift yönlü, çevresel) ve theatron (seyir mekânı) sözcüklerinden oluşan amfitiyatro, bir seyirlik merkez çevresinde kalabalık bir seyirci topluluğunun yerleşmesine izin veren geniş bir mekândır (Bomgardner, 2001, s. 36-39). Illk çağlarda, ateşin çevresinde toplanıp bir şamanın, bir avcının ya da bir bilgenin hikâye anlatmasını izleyen kabileyi düşünelim. Bu seyirlik, kabile için duygusal, bedensel ve ruhsal bir paylaşımdır. Ortada yanan ateşin çevresinde farklı gözleri, akılları ve bedenleri aynı deneyimde buluşturan bir beraberlik yaşanır. Sadece bu mekânda bulunan kişiler arasında değil, geçmiş kuşaklardan yeni kuşaklara aktarılan bir tecrübe de söz konusudur bu arkaik gösteri formunda. Kabiledeki dayanışmanın ve birliğin sürmesi açısından, bu geleneğin yaşamsal bir önemi vardır. Göçebe hayattan şehir yerleşimine geçilmeye başlandığında, bu geleneğin sürdürüleceği mekân giderek daha sabit bir şekle bürünür ve tarihsel anlamda theatron ortaya çıkar (Wiles, 2000, s. 26-48) 
Amfitiyatro formundaki ilk mekânlar, bir tepenin yamacında sıralanan oturma yerlerini tamamlayan merkezî, küçük bir sahneden ibarettir. Burada önem arz eden unsur, şehir halkının herhangi bir toplu seyirlik için, hep burada, aynı mekânda toplanmasıdır (Storey ve Allan, s. 34-46). Theatron, topluluğun beraberliğini görsel olarak simgeleyen ve bu beraberliğe yuva oluşturan bir ana rahmi biçimindedir.

Bugün kavradığımız şekliyle drama sanatının gelişmesi, bu amfitiyatro biçimselliğinin tarihsel dönüşümüyle paralel bir eksende incelenebilir (Walton, 2015, s. 1-57).

Milattan önce 6. yüzyıl sonları, Yunan halklarının Perslerle yaşanan çok uzun bir savaş döneminden dayanışma içinde çıktığı dönem olarak kabul edilir. Bu dönemde, bugün anladığımız şekliyle demokrasi kavramının ilk denemeleri ortaya çıkar (Bonnard, 1962). Tarihte bilinen ilk (ve en uzun ömürlü) tiyatro festivali City Dionysia, bu dönemde oluşmuştur. Atina'da, yılda bir kez, bahar mevsimine girilirken düzenlenen bu tiyatro festivali bereket, yaşam ve ölüm tanrısı olarak bilinen Dionysos onuruna gerçekleştirilmiştir. (Rehm, 2005, s. 2-75) Milattan önce 5. yüzyıl, Atina halkının siyasal ve hukuksal düzeni demokratik oylama yöntemiyle yürüttüğü bir dönemdir. Bu yüzyıl boyunca tiyatro festivalleri, yılda üç kez gerçekleștirilmek üzere yaygınlaşır ve kent yașamının en önemli etkinliği haline gelir. Bu süreçte, tiyatro mekânı giderek amfitiyatro biçimini alır ve dönemin ihtiyaçlarına göre değişikliklere uğrayarak genişler (Beacham, 2007, s. 201-227).

Figür 1. M.Ö. 4. yüzyılda Atina'daki amfitiyatroyu temsil eden bir gravür. (Kaynak: https:// www.istockphoto.com/tr/vektör/dionysosantik-tiyatro-atina-yeniden-inşası-gm1015474676-273281632)

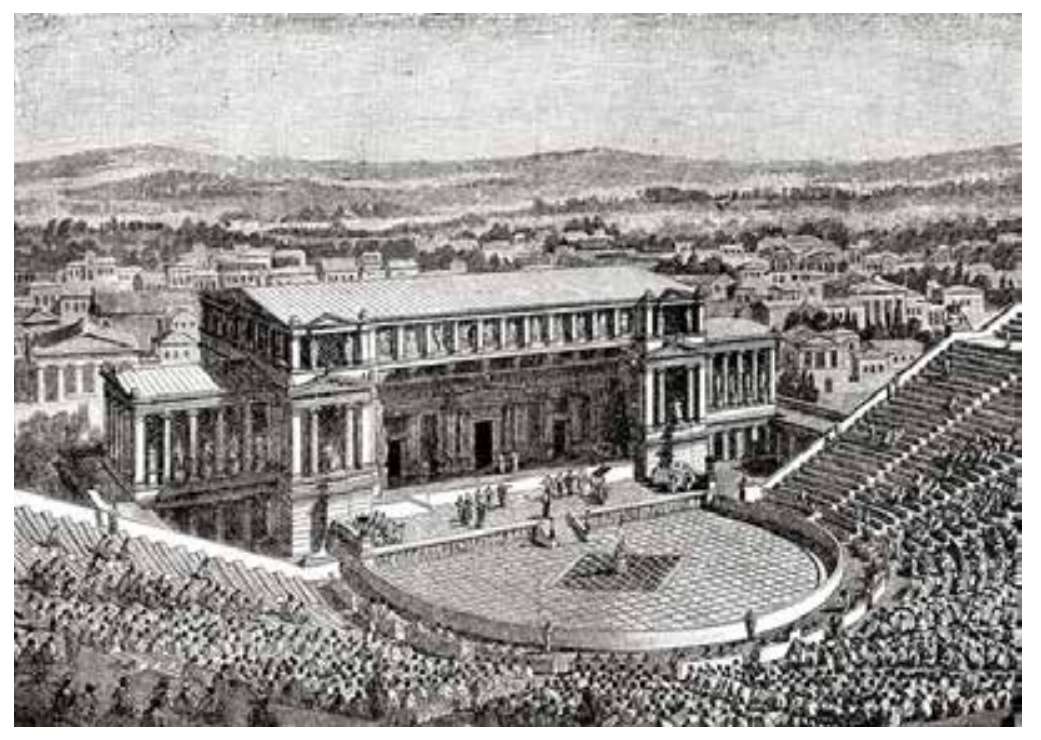

Tiyatro, bu dönemin şehir düzeninde yaşamsal bir işlev üstlenmiştir. Devletin resmî bir eğitim sisteminin bulunmadığı bu düzende, şehir yönetiminde söz sahibi olan vatandaşların iletişim, mücadele ve uzlaşma mekânı tiyatrodur. Tiyatro temsillerini izlemek, bu etkinlik sırasında amfitiyatroda bulunmak, bir vatandaşlık görevidir. Devlet, zengin vatandaşlar arasından seçtiği kişileri, tiyatro mekânlarını ve temsillerini finanse etmek üzere sorumlu kılmıştır. Tiyatro festivalinde sergilenecek oyunlar, önceden seçilerek belirlenir. Seçilen oyunların aylarca süren hazırlık ve temsillerinde görev almak da vatandaşlık görevleri arasındadır (Roselli, 2011).

Sahneye koyulan oyunlar, topluluğun o dönemdeki değer yargılarını, ahlâki kaygılarını, siyasal çatışmalarını, uzlaşma arayışlarını ortaya getirir. Toplumun çok çeşitli kesimlerinin ve meselelerinin sahnede ifade bulmasına ve dolaşıma girmesine imkân sağlar. Şehirdeki amfitiyatro, şehrin kültürel merkezi konumundadır. Bu dönemde ekonomik ve kültürel açıdan giderek zenginleșen Atina, tiyatro festivalleri kanalıyla ekonomik, toplumsal ve siyasî varlığını vatandaşlarına ve ziyaretçilerine sergileme imkânını bulur (Arnott, 2003).

Oyunların temsilini seyirci olarak binlerce kişi izler. Sahneye en yakın sıralarda din adamları, komutanlar, yabancı şehirlerden gelen nüfuzlu elçiler, savaşta ölen askerlerin çocukları, şehrin zengin vergi mükellefleri oturur. Köklü ailelerin temsilcileri ve önemli ziyaretçiler ayrı bir bölümde yer bulur. Sıradan vatandașlar sahneye daha uzak sıralara yerleşir. Kadınlar, çocuklar ve köleler ancak sahneye en uzak sıralarda yer alabilir (Roselli, 2011). Demokrasinin bu uygulamasında kadınlar, çocuklar ve köleler oy hakkına sahip değildir. Ancak oyunların içeriğindeki tarihsel değişim incelendiğinde, kadınların, çocukların, kölelerin giderek görünürlük kazanan biçimlerde temsil edildiği söylenebilir (Hall, 2006).

M.Ö. 5. yüzyılda tiyatro ve drama sürekli gelişerek, Yunan şehir devletlerindeki toplumsal yapının vazgeçilmez unsuru haline gelmiştir. Şehir hayatının merkezindeki mekân, amfitiyatrodur. Bu yüzyıldan önceki amfitiyatro yapıları tahtadan inşa edilirken, bu dönemde amfitiyatro mekânlarında taş ve mermer kullanılmaya başlanır. Amfitiyatronun sahnesi, büyük bir koroya ve hareketli eyleme izin veren şekilde, devasa boyuttadır. Seyircilerin oturduğu bölüm yaklaşık 15 bin kişiyi alacak şekilde büyütülür. Ses sistemi, bugünün standartlarıyla bile mükemmel bir matematiksel hesapla ayarlanmıştı. Sahnenin arka planında skene adı verilen uzun, düz bir yapı yer alır. Bu yapı, sahnedeki oyuna dekor ve arka plan oluşturma, aynı zamanda ses sistemini dengeleme işlevlerini görür. Tiyatro mekânı geliştikçe ve büyüdükçe, skene aktörlerin kostüm değiştirmesine, içinden sahneye girip çıkmasına izin veren bir forma kavuşur. Öyle ki, M.Ö. 4. yüzyıl başına gelindiğinde, skene iki katlı, çok kapılı, her oyunda farklı biçimlerde kullanılan çok işlevli bir yapı olmuştur (Wiles, 1997; Powers, 2014).

M.Ö. 4. yüzyılda Yunan kültürü ağırlık kazanarak, Yunan yarımadasının doğusuna ve batısına doğru alabildiğine genișler. Helenistik dönem olarak bilinen bu dönemde, her şehrin merkezinde bir amfitiyatro inşa edilir (Moretti, 2014). Tiyat- 
ro temsilleri, şehir hayatını düzenleyen ilișkilerin merkezinde yer alır. Bir önceki yüzyılda tragedya ve komedya formlarının son derece yetkin bir düzeye ulaştığı, bugün elimize ulaşan eserlerde görülmektedir (Oates ve O'Neill, 1938). Helenistik döneme kadar, tragedya temsilinde dinsel ve ahlâkî nitelik baskın konumdadır. Öyle ki, tragedya kelimesi tragos (keçi) ve odie (ağıt) kelimelerinden oluşur: Bu isim, temsillerin sonunda ilâhi kudret onuruna kurban edilen hayvanlarla ilişkilendirilir (Adrados, 2017, s. 3-15). Helenistik dönem, tiyatro temsillerinin sadece dinsel birer âyin olarak değil, her türlü toplumsal buluşmayı onurlandıran bir ritüel olarak gerçekleştirilmeye başladığı dönemdir. Nüfuzlu ve varlıklı kişiler, nüfuzlarını devamlı kılmak ve halkın gözünde değerli olabilmek için tiyatro temsillerinin ve amfitiyatroların devamlılığını sağlamaktadır. Ancak bu durum, tiyatro oyunlarının içeriğini ve formunu etkileyecektir. Kahramanın ağır sonuçları yüklenerek ahlâki bir örnek oluşturduğu tragedya formu, her dönemde aşılanmak istenen değerleri yüceltmek üzere kullanılır. Komedya formu da dönüșüme uğrayarak, halkın hoș vakit geçirmesini ve kadere hoşça boyun eğmesini destekleyen anlatılar ortaya koyar (Csapo vd., 2014).

Figür 2. Atina'daki Herodes Atticus tiyatrosunun restore edilmiş durumu. (Kaynak:https://commons.wikimedia.org/wiki/File:Athens_ cityscape_from_the_Odeon_of_Herodes_Atticus._Athens,_Greece.jpg)

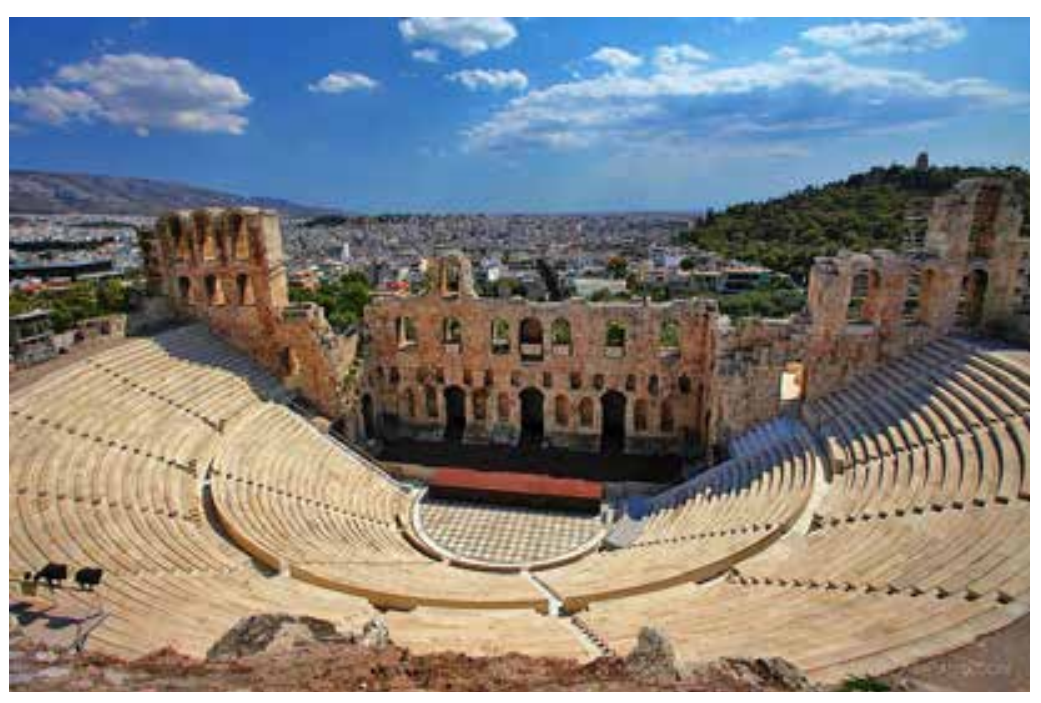

M.Ö. 509'da kurulan Roma Cumhuriyeti, Yunan kültürünü kendi koşullarına ve Latinceye uyarlayarak büyük ölçüde sürdürmüştür. Şehir yaşamının amfitiyatro çevresinde şekillendiği bir kültür Roma'da da söz konusudur; ancak yöneticiler tiyatro temsillerinin ağırlık kazanmasına karşı çıktıkları için, taş ve mermerle inşa edilen ilk sabit tiyatro mekânı ancak M.O. 70 civarında, Pompey'de kurulmuştur. (Bomgardner, 2001, s. 36-42). Bu tarihte Roma artık bir cumhuriyet değil, baskıcı generallerin yönettiği bir imparatorluktur. Pompey amfitiyatrosu, 20 bin seyirci alabilen, sahnede haşmetli bir skene ile donatılmış, hükmedicilerin heykelleriyle süslü, generallerin kudretini ezici bir şekilde halka temâşa ettiren bir güç abidesidir. Bu tarihten itibaren Roma sehirlerinde cok sayıda sabit amfitiyatro inşa edilecek; her biri, yöneticilerin gücünü, dünyevî kudreti, aşırılığı ve abartıyı kutlayan birer anıt olacaktır. Yarım daire biçimindeki amfitiyatrodan, tam daire biçiminde amfitiyatrolara geçiş bu dönemde olur. Tam daire, Roma devletinin tüm dünyaya hâkim olduğu düşünülen gücünü daha iyi yansıtmaktadır (Sear, 2006, s. 1-118) Amfitiyatro mekânındaki bu dönüşüm, tiyatro temsillerindeki dönüşümle birlikte incelenmelidir. Roma tiyatrosunda, düşünmeyi ve ahlâkî temellere dayalı bir yaşam biçimini destekleyen oyunlar, M.Ö. 4. yüzyılda, sadece eğitimli, elit, sınırlı sayıda seyirciye yönelik bir ortamda gerçekleşir. Bunun dışında, Roma tiyatrosunda giderek ağırlık kazanan tercihler, abartılı bir eğlenceyi yücelten, incelikten yoksun, gösterișli ve gösterișçi oyunlara yöneliktir. (Manuwald, 2011) Bu eğilim giderek kuvvetlenecek; amfitiyatrolarda izlenen drama temsilleri yerini sirk gösterilerine, abartılı savaş oyunlarına, hayvanların ve insanların gösteriş için katledildiği gladyatör müsabakalarına bırakacaktır (Beacham, 1991).

Figür 3. M.S. 72' de yapımı tamamlanan Colosseum, Roma. Yaklaşık 80 kapıdan elli bin seyircinin girip çıkabildiği, dünyanın en büyük dairesel amfitiyatrosu. (Kaynak: https://www.touropia.com/ roman-amphitheaters/)

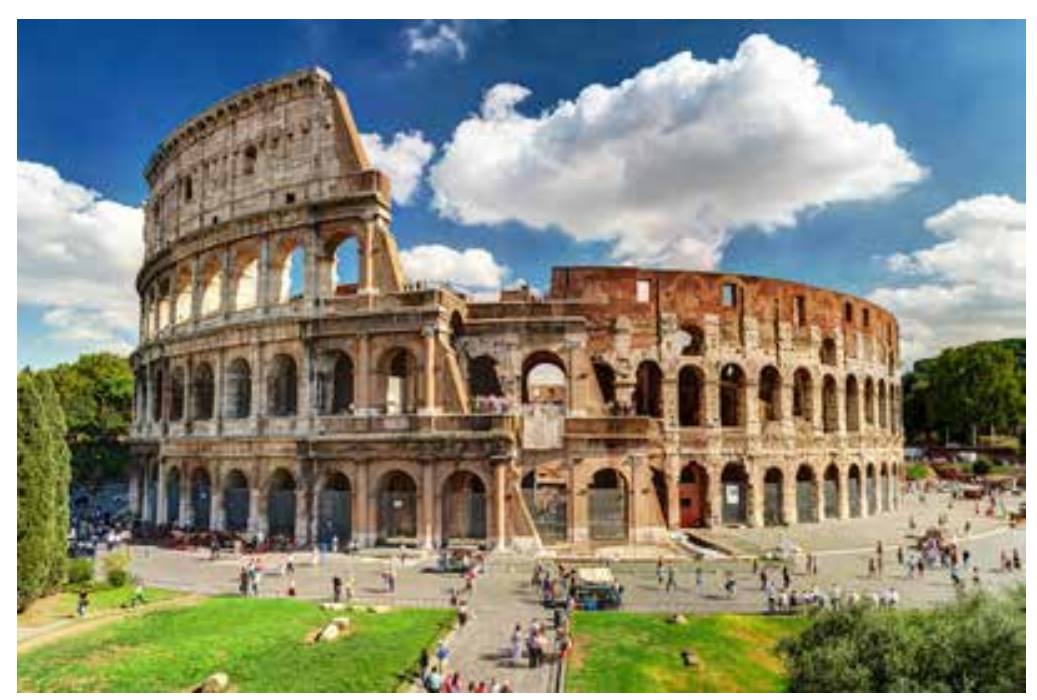

\section{Antik Dönemden Orta Çağa...}

Hristiyanlık öğretisinin Roma şehirlerinin yaşantısına girmeye başlamasıyla, tiyatro alanında yeni bir mücadele baş gösterir. Alçakgönüllülüğü, aza kanaat etmeyi, 
dürüst davranmayı, günahlardan arınmak üzere erdemli yaşamayı öğütleyen Hristiyan öğretisi, her türlü aşırılığı, şiddeti ve dünyevî gösterişi yücelten amfitiyatro gösterilerinin karşısında durur. Bu kavganın ilk aşamalarında tiyatro gösterileri, Hristiyan keşişlerini aşağılamak ve gülünç göstermek için tüm silâhlarını kullanır. (Scullard, 1981; Graf, 2015). Ancak Roma İmparatoru Konstantin'in 312 yılında Hristiyanlığı Roma'nın resmî dini ilân etmesiyle işler değişmeye başlar. 410 yılında Vizigot'ların Roma şehrini ele geçirmesiyle de, Roma Imparatorluğunun şaşaalı günleri sona erer ve bütün amfitiyatrolar gösterilere kapatılır (Bomgardner, 2001, s. 197-220).

Hristiyan öğretisinin ağırlık kazanması, Pagan geleneklerin uyarlanarak yeni görünümlere bürünmesine yol açacaktır. Ancak bu yüzyıllarda amfitiyatro gösterileri tarih sahnesinden bir süreliğine yok olacaktır. Bu yok oluşun temel nedenleri, dinsel alanda değil, ekonomik koşullarda aranmalıdır. Eski Roma İmparatorluğu'nun topraklarında, hayatta kalmayı son derece zor kılan bir yoksulluk, savas ve göçebelik hali hüküm sürmektedir. Hristiyan Kilisesi denetimindeki bu bölgede tiyatro kültürünün yeniden canlanması, ancak 10. ve 11. yüzyıllarda mümkün olacaktır (Graf, 2015, s. 239-320).

Bu döneme gelindiğinde, eski tiyatro kültürünün izleri, birkaç mecranın aktarım imkânları sayesinde canlı kalmıştır. Bunlardan birincisi, şehirden şehre gezerek meydanlarda gösteri yapan göçebe oyuncu topluluklarıdır. İkincisi, en yoksul dönemlerde bile halkın ihtiyaç duyduğu ve sürdürdüğü, mevsim dönüşlerinde gerçekleşen karnaval geleneğidir. Üçüncüsü, antik dönemden kalan ve tercüme edilerek okunan Yunanca ve Latince tragedya ve komedya metinleridir. Bir diğeri de, soylu sınıfın şölen sofralarında ve salonlarında gerçekleştirilen temsillerdir. 11. yüzyıla gelindiğinde, tüm bunların Kilise'nin otoritesi ve yönetiminde yeni bir tiyatro kültürü oluşturmaya başladığı gözlenebilir (Wickham, 1992, s. 68-80).

Hristiyan din adamları, o güne kadar kilise duvarlarındaki mozaik ve fresklerle, rahiplerin vaazlarıyla aktarılan Incil mesajlarını birer tiyatro temsili biçiminde sergilemenin çok daha etkili olduğunu keşfetmiştir. Bu iş için eğitim alan genç rahipler kasaba, köy ve şehirler arasında gezerek bu temsilleri sergileme misyonunu üstlenirler. Şehirlerde en büyük gösteriler, yılda beş kez gerçekleşen dini bayramlar sırasında gerçekleşir. Bu bayramlarda, içeriği ve icrâsı Kilise tarafından denetlenen, hazırlığı aylar süren, maliyetinin Kilise denetimindeki şehir meslek gruplarınca karşılandığı oyunlar sergilenir. Incil mesellerini, azizlerin hayatlarından kesitleri, öğretici ve ibret verici hikâyeleri tiyatro metinlerine dönüştürmek, manastırdaki öğrencilerin ve rahiplerin görevidir. Oyunculuk görevinin de aynı kişilerce üstlenildiği anlaşımaktadır (Wickham, 1992, s. 80-96).

Oyunların sahnelenmesi için bu dönemde mekân olarak manastır ve kilise avluları, pazar yerlerinde ve meydanlarda geçici olarak kurulan yapılar kullanılır. Şehir halkının bu oyunları izlemesi, kültürel bir ihtiyaç olmaktan öte, toplumsal ve dinsel bir vazifedir. 14. yüzyıla gelindiğinde, Katolik Kilisesi'nin kontrolündeki tiyatro, şehir hayatındaki başlıca eğitim kurumu olarak etkili bir denetim mekanizmasına dönüşmüştür (Fischer-Lichte, 2002, s. 33-50).
Figür 4. Ortaçağdaki dinsel bir dramayı temsil eden gravür. (Kaynak: https://historicinterpreter.wordpress.com/2015/03/16/

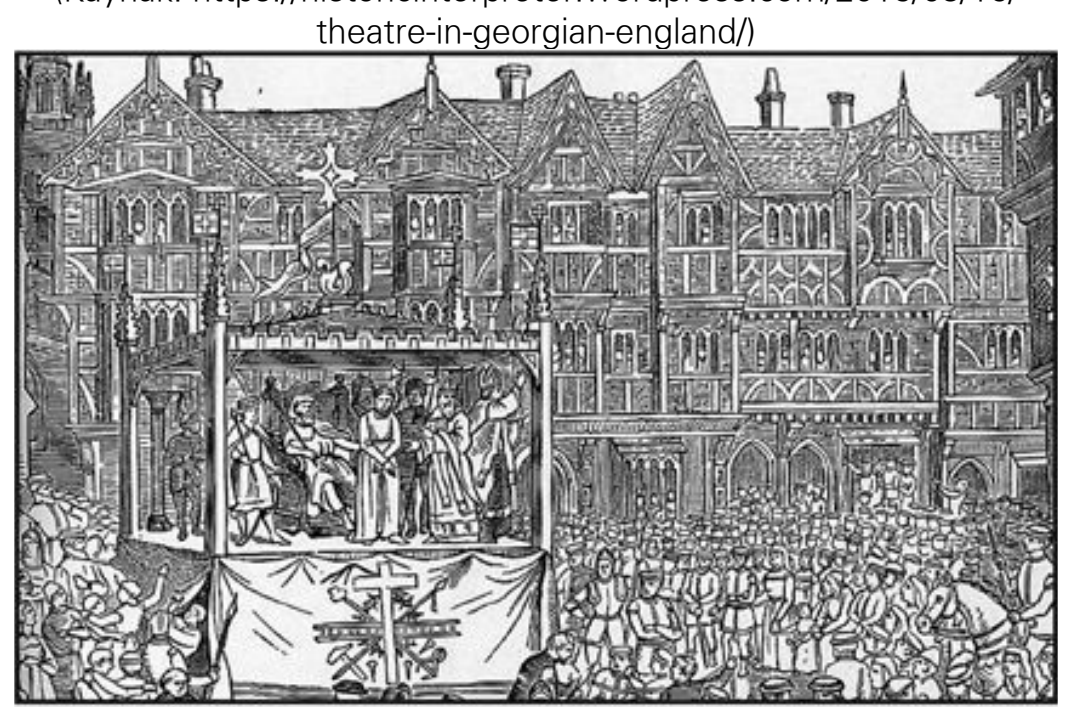

14. yüzyılda tiyatro, Romanesk tarzdan Gotik tarza doğru bir dönüşüm geçirir. Tiyatro oyunları yine tamamen dinsel içerikli olmayı sürdürür, ancak hikâyelere getirilen bakış açısı değişmiştir: Romanesk tarzda ilâhi kudretin görünmez ve bilinmez boyutuna vurgu yapılırken, Gotik tarzdaki gösteriler, peygamberin ve azizlerin dünyada çektikleri acıları, eziyeti ve çileyi öne çıkarır. Tanrının insanlarla hangi yollardan, ne şekilde ilişki kurduğunu seyircilere öğretmek için tiyatroda, eskisine göre çok daha detaylı ve günlük hayatın her türlü unsuruyla zenginleştirilen bir anlatı tarzı kullanılmaktadır. Çarpıcı kontrastlar, fantezinin sert bir gerçekçilikle iç içe kullanılması, günlük hayatı zengin metaforlarla yorumlayabilmek, bu tiyatro yaklaşımının ifade imkânlarını genişletir (Scherb, 2001).

Bu temsiller, şehirdeki sosyal hayatın temel bir unsuru haline geldiği için, her türden kent mekânı kolaylıkla bir gösteri yerine dönüşebilmektedir. Meydanlar, yol kavşakları, ortak yapıların avlu ve salonları intiyaca göre geçici birer tiyatro mekânı oluşturur. Dinsel bayramlarda bu mekânların boyutu alabildiğine geniș tutulur ve mekân hazırlığında halkın büyük bölümü seferber edilir (Sturges, 2015).

16. yüzyıldan önce tiyatronun, her türlü eğitim ve ifade imkânını bünyesine taşımış olan Katolik Kilisesi'nin denetiminde bulunduğunu unutmamak gerekir. Ancak, 16. yüzyıl başından itibaren önce Almanya ve İsviçre bölgesinde, daha sonra Britanya'da gelișen dinsel reform hareketi, bu durumu değiştirecektir. Bu tarihten itibaren tiyatro, Protestan hareketin Katolik otoriteyle mücadelesinin en önemli arenalarından birisi haline gelir (Fischer-Lichte, 2002, s. 50-97). 


\section{Aristokrasinin Kiliseyle Mücadelesi}

Reform hareketiyle eş zamanlı yürüyen diğer bir gelişme de, milliyetçi aristokrasinin güç kazanmasıdır. Denizaşırı keşiflerin ve ticaretin getirdiği ilișkilerle zenginleşen aristokrasi, artık kilisenin otoritesinde tek merkezden yönetilmeye boyun eğmeyecektir. Protestan ve Katolik kiliseleri arasındaki çekişmeyi besleyen ekonomik ve siyasî arka planda yeni bir iktidar mücadelesi şekillenmektedir (Wickham, 1992, s. 68-96).

Figür 5. Theatrum Vitae Humanae isimli ve 1596 tarihli gravür.

(Kaynak: https://archive.org/details/theatrumvitaehum00bois/page/n4)

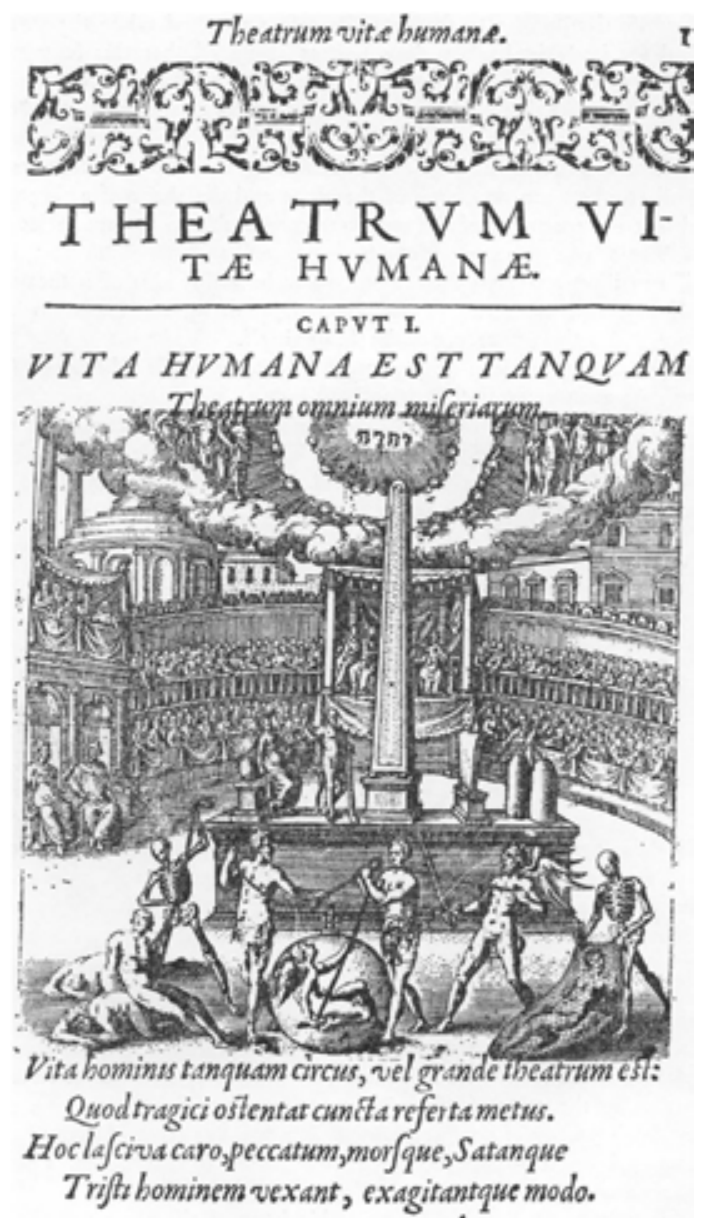

A

Bu dönemde tiyatro gösterilerinde temel olarak şöyle bir dönüşüm gerçekleşecektir: Hristiyan öğretisinin rehberliğinde 16. yüzylla kadar olgunlaşan dünya görüşüne göre kişi, dairesel bir amfitiyatroda, hiyerarşik düzende göğe doğru yükselen ilâhi güçler huzurunda izlenmekte ve bu dünyanın sahnesinde, bir mahkemede bulunmaktadır. Kiși, bu dünyadaki hareketlerine, ilâhi amfitiyatrodaki seyircilerin huzurunda olduğunun bilinciyle yön vermelidir. Dünyanın bir tiyatro olduğunu söyleyen bu görüş, 4. yüzyıldan itibaren Theatrum Mundi metaforuyla ifade bulmuştur. 16. yüzyıldan sonra Theatrum Mundi metaforu, tam tersi yönü işaret edecek șekilde dönüșür. Yeni dönemde sahnede, milliyetçi devletin hükümdarı, kral yer alır. Onun çevresinde de hiyerarşik ve dairesel bir düzende, devletin diğer yöneticileri sıralanır. Sahneye en uzak bulunanlar, devlet için en önemsiz ve en güçsüz vatandaşlar olacaktır. Burada ilâhi bir mahkeme değil, merkezdeki dünyevi bir güce tapınma ritüeli söz konusudur (Bernheimer, 1956; Egginton, 2003, s. 33-67).

Tiyatro mekânlarında da, bu dönüşümü bire bir yansıtan bir değişim gerçekleşmektedir. Dönemin mimar ve sanatçı ustaları, kralın ve çevresindekilerin dünyevî kudretini sergileyecek tiyatro salonlarını inşa etmekle görevlidir. Matbaanın etkinleşmesi, antik tragedya ve komedya metinlerinin Yunanca ve Latince asıllarından tercüme edilerek çoğaltılmasını mümkün kılmıştır. Bu metinlerden esinlenen yeni tiyatro oyunlarını, dönemin aristokrasisini onurlandıracak içeriklerle oluşturma görevi, yeni dönemin eğitimli yazarlarına verilir (Postlewate ve Hüsken, 2007).

Kilisenin otoritesinden çıkarak gelișmeye devam eden tiyatro kültürünün iki koldan ilerlediği görülür: Sadece aristokrasinin girebildiği tiyatro salonları için yazılan oyunlar ve sadece halk için, meydanlarda ve açık alanlarda sergilenen oyunlar. Ancak bir süre sonra iki kolun birbiriyle bulușmasını sağlayan durumlar ortaya çıkar. Öncelikle, aristokrasi zenginliğini ve gücünü sadece kendisi için sergilemekle yetinmeyecek ve bu ayrıcalığı, topluluğun hayranlığını ve saygısını uyandıracak biçimde gösterişe dönüștürmek isteyecektir. Bu yüzden, saray halkının kendisini halk tarafından izlenmeye sunduğu halka açık geçit törenleri, düğünler ve şölenler düzenlenecektir. Bu gösterilerin anlatısallık ve dramatizasyon açısından, birer tiyatro gösterisinden fazla farkı olmayacaktır. Bu gösterilerde tüm kent alanının ve böylece dünyasal arenanın, aristokrasinin iktidarını destekleyen bir tiyatro mekânına dönüştürüldüğü söylenebilir. (Fischer-Lichte, 2002, s. 97-129; Wickham, 1992, s. 68-96).

16. yüzyılda İngiltere, olağanüstü bir tiyatro kültürünün gelişimine sahne olur. Kraliyet ve çevresindeki aristokrasi, Katolik kilisesinden bağımsızlığını ilan ettikten sonra, çoğunluğu okuryazar olmayan halkı yönlendirme, eğitme, korkutma ve denetleme işini tiyatro üzerinden gerçekleştirir. Tiyatro mekânlarını, işletmecilerini ve sanatçılarını sıkı bir denetim altında tutar. Oyunlara sansür uygulama ve müdahale hakkı kralın elindedir. Dolayısıyla, susturulması gereken zümreler hain, kötü ve gülünç; alkışlanması gereken kesimler de güçlü, akıllı ve hayran olunası karakterler olarak temsil edilir (Leggatt, 1992).

Bu dönemde ortalama büyüklükte bir şehir tiyatrosunun iki bin seyirci alması beklenir. Sahne, en az kırk metrekare genişliğinde olmalıdır. Sahne gerisinde, aktörlerin içine girip çıkacağı, giysi değiştireceği, aynı zamanda dekora arka plan 
oluşturan yapı bulunur. Dairesel formda, yukarıya doğru yükselen seyirci koltukları, antik tiyatro mekânlarının planını mümkün olduğunca tekrarlamaktadır. Halka açık tiyatrolarda bilet fiyatları ve sosyal statü, üst sıralara doğru yükselir. Öte yandan, sadece aristokrasinin girebildiği tiyatrolarda, soyluluk rütbesi üst sıralara doğru azalır (Low ve Myhill, 2011; Leggatt, 1992, s. 9-47).

Figür 6. Aslına sadık biçimde restore edilerek günümüzde de kullanılan Shakespeare'in Globe Tiyatrosu. Londra'nın sadece tiyatro oyunları için inşa edilen ilk mekânı olarak, 1576'da açılmıştı. (Kaynak: IKIhttps://www.thestage.co.uk/opinion/2016/editors-viewnext-shakespeares-globe/)

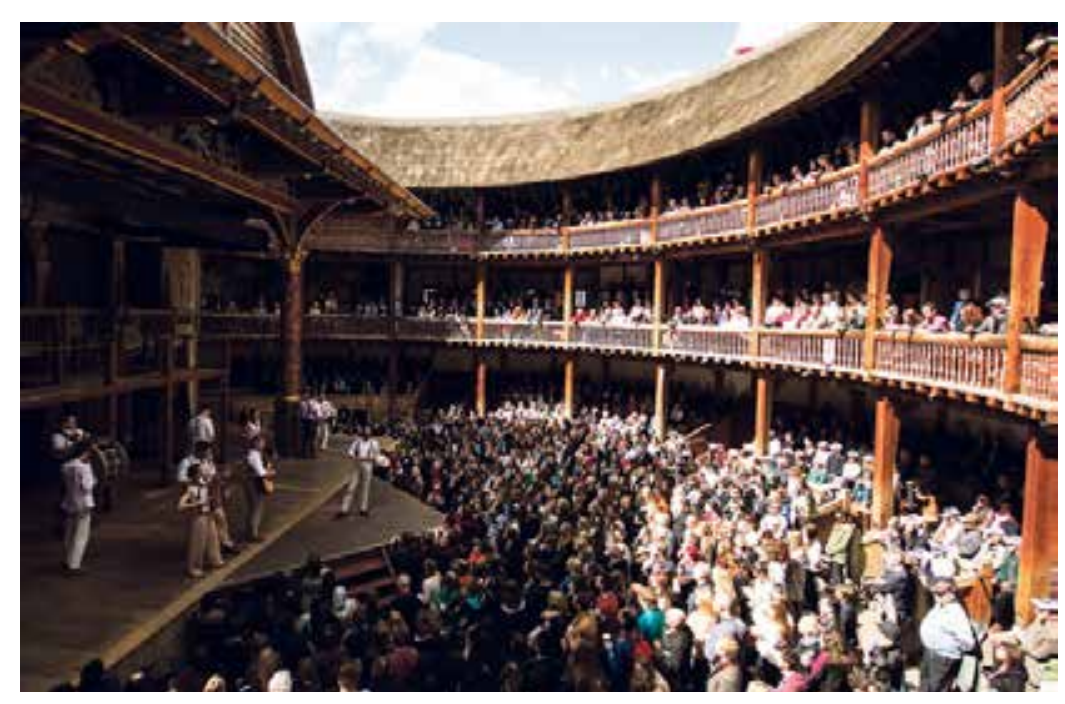

Bu ortamda, birbiriyle kıyasıya rekabete giren tiyatro grupları ve bu grupların kendilerine ait tiyatro salonları mevcuttur. Bilet fiyatları sahneye uzaklık konumuna göre değişir ancak şu kesindir ki, halkın her kesimi bu tiyatro salonlarını doldurmakta ve dönemin mücadelelerini, tiyatro oyunlarında bire bir izlemektedir (Lopez, 2003). Bu dönemde seyircilerin sesli yorumlarla oyuna katılması hiç yadırganan bir durum değildir. Seyirci büyük bir dikkatle sahneyi izler; beğenisini, hayranlığını ya da sıkıntısını derhal yüksek sesle ifade eder. Kolay aldatılan ve azla yetinen bir seyirci kitlesi söz konusu değildir (Fitzpatrick, 2011; Arnold, 2015) William Shakespeare gibi bir yazarın yetkinliği bu eserlerin hangi koşullarda, hangi kaynaklardan beslenerek ortaya çıktığını düșündüğümüzde daha derin bir anlam kazanır (Greenblatt, 2014).

Kilise ve tiyatro arasındaki, Katolik ve Protestan mezheplerinin çekişmesini yansıtan mücadele 16. Yüzyıl boyunca artarak sürer ve iç savașın șiddetlenmesi, Ingiltere'de 1642 'de bütün tiyatroların kapatılmasına yol açar. (Wickham, 1992, s. 113-115).
Figür 7. XIV Louis tarafından yaptırılarak 1669'da açlan Paris Operası'nın günümüzdeki restore edilmiş durumu. (Kaynak: https:// en.parisinfo.com/paris-museum-monument/71227/Opera-Nationalde-Paris-Palais-Garnier)

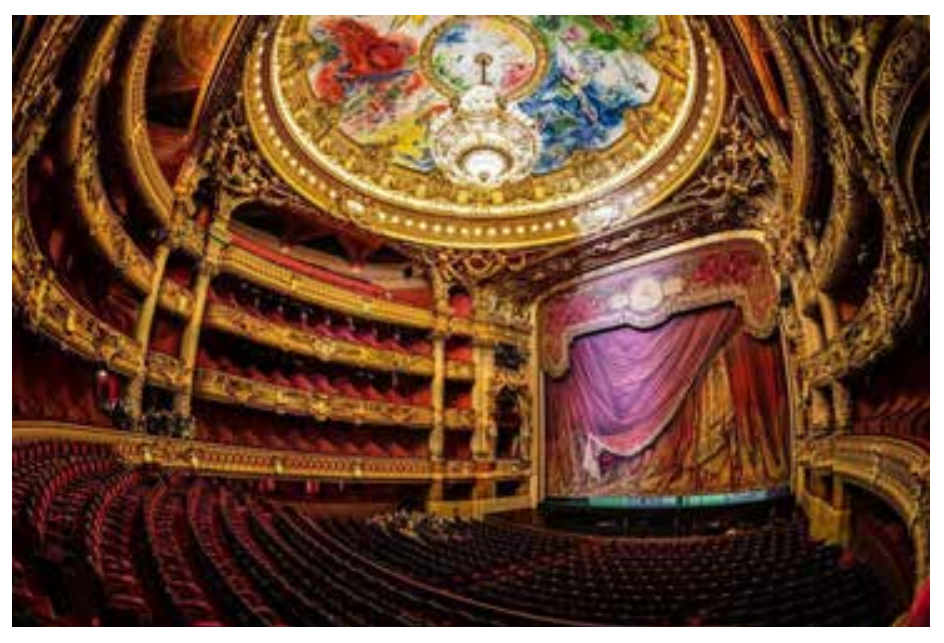

Figür 8. Yapımı $1737^{\prime}$ de tamamlanan ve günümüzde opera salonu olarak kullanılan San Carlo Tiyatrosu (Napoli). (Kaynak: https:// www. pandotrip.com/top-10-opera-houses-in-the-world-17123/

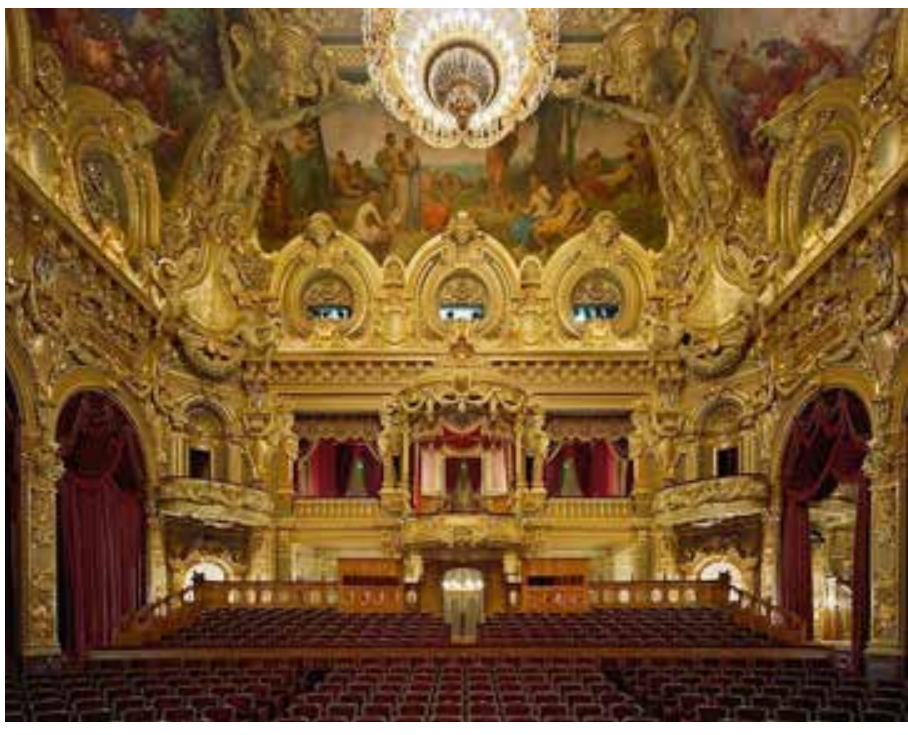

Öte yandan, Fransa'da mezhebe dayalı iç savaş dönemi 16. yüzyılda yaşanmıştır. Bu dönemde tiyatronun oluşturabileceği tehdit, aristokrasinin Kilise ile iş- 
birliği yaparak tiyatro gösterilerini tümüyle yasaklamasına yol açmıştır. Ancak 17. yüzyıl başında, aristokrasi tiyatroyu denetimine alacak güveni kendinde bulmaya başlar. 1634 yılında kraliyetin emriyle kurulan Académie Française, dönemin entelektüellerini bünyesinde toplar ve tiyatronun nasıl olması gerektiğini belirleme görevini üstlenir. Bu yüzyıl boyunca Corneille, Molière, Racine başta olmak üzere dönemin düşünürleri ve sanatçıları, aristokrasinin denetiminde kapsamlı ve otoriter bir tiyatro kuramı olușturacaktır (Kadler, 1969, s. 1-68). Öyle ki, 17. Yüzyıl sonunda tiyatro, şehirde sürdürülmesi gereken yaşam tarzının ve bakış açısının kurallarını yazan ve sergileyen en önemli kurum haline gelir (Wickham, 1992, s. 145-158; Auchincloss, 1996).

Bu tiyatro yaklaşımında abartı, duygusallık ve romantizm küçümsenir. İnsan, aklıyla insanlığını kazanan bir varlık olmalıdır. Bu yüzden de insan doğası büyük bir gerçekçilikle, aklın muhâkemesinden geçerek yansıtılmalıdır. Bu tiyatroda aşırı duygu iniş çıkışları, mucizevi olaylar, sebebi anlaşımayan tutumlar, şiddetli davranışlar, abartılı hareketler, keskin hikâye dönüşleri olmamalıdır. İzleyiciyi akla ve sağduyuya davet eden karakter ve tutumlar sergilenmelidir (Jondorf, 1990; Greenberg, 2010)

17. yüzyılda Fransa'da gelişen bu tiyatro yaklaşımı, Avrupa'nın diğer coğrafyalarında da aristokrasi ve entelektüeller kanalıyla saygınlık kazanır. Öyle ki, Ingiltere'de dahi, monarşinin tekrar yönetimi ele geçirdiği ve tiyatroların yeniden açılmaya başladığı 1660 yıından itibaren, eski tiyatro anlayışının yeni kurallara uyumlanarak dönüşüme uğradığı görülür. Kadınların da sahnede oyunculuk yapması, ilk kez bu dönemde mümkün olacaktır (Cordner, 2007). Tiyatro yaklaşımlarındaki bu gerçekçilik arayışı sırasında, aristokratik tiyatro mekânlarında farklı bir tarz yükselişe geçmiştir: Müzikal tiyatro oyunları; yani, opera. Tiyatro oyunlarındaki sadeleșme ve akılcılașma baskısı yüzünden fantezi, abartı ve romantizm bütün enerjisiyle opera mekânlarında ifade bulmuş gibidir (Wickham, 1992, s. 173-176).

\section{Sınıf Mücadelesinde Yeni Oyuncular}

Bu dönemde müzikli ya da müziksiz tüm tiyatro oyunlarındaki ortak eğilim, yükselmekte olan burjuvazinin hırsını, özentiliğini, gülünçlüklerini sergilemek yönündedir. Zira, Avrupa'da maddi zenginliğin artması ve servetin el değiştirebilir olması sayesinde şehirlerde yeni bir sınıf, yani burjuvazi ortaya çıkmaktadır. Toplumsal planda gücünün bu yeni sınıfın eline geçmesini istemeyen aristokrasi ve entelektüel kesim de, mücadelesini sahnede vermektedir (Prest, 2014).

Bu mücadelenin karşı hareketi de oluşmakta gecikmeyecektir. Burjuvazinin sürekli zenginlik ve güç kazandığı 18. yüzyıldaki tiyatro mekânlarında melodram, en sevilen tarz olarak bütün cesametiyle yükselir. Inandırııılık ve gerçekçiliğe ihtiyaç yoktur; mucizeler, hoş sürprizler, felâketler, olağanüstü zaferler birbiri ardına sıralanabilir. Böyle olması tercih edilir. Sevinç, üzüntü, korku, şehvet, intikam tüm haşmetleriyle sahnede yer almalı; faziletli kahramanlar ne olursa olsun ödüllendi- rilmeli, alçak ve hainler de aynı anda cezalarını bulmalıdır (Fischer-Lichte, 2002, s. 202-284; Greenberg 1992).

Avrupa'da burjuvazinin ve maddî zenginliğin yükselmesi, tiyatro mekânlarının sayısında hızlı bir artışa yol açarken, bu mekânlardaki teknik imkânlar da önemli ölçüde gelişir. Bu mekân ve imkânlar, burjuvazinin arzularını yansıtan ahlâkçı ve romantik bir tiyatronun hizmetindedir. Ancak dönemin saygın düşünür ve yazarları tiyatrodaki ilkelerin ne olması gerektiğini tartışırken, mevcut tiyatro oyunlarını kıyasıya eleştirmekten geri durmazlar. Bu eleştirileri destekleyen aristokrasi de, gösteri ve mekânlara yasaklar getirir, müdahale eder ve bunu gerektiğinde zor kullanarak yapar (Carles, 2016; Wiles, 2014).

Figür 9. 1810 tarihli bir resimde Londra'daki Royal Circus Tiyatrosu. (Kaynak:https://commons.wikimedia.org/wiki/ File:Microcosm_of_London_Plate_066_-_Royal_Circus.jpg)

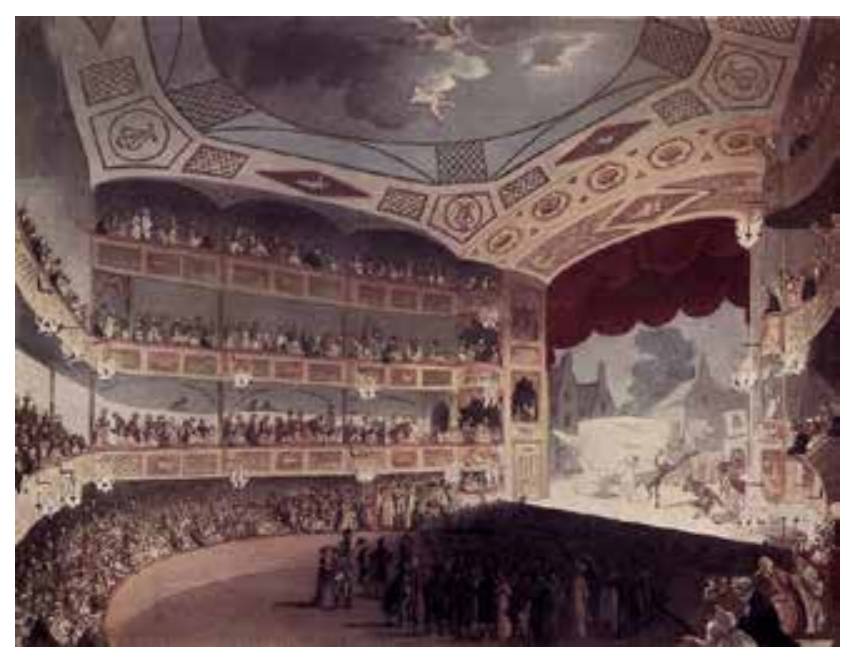

19. yüzyıl kavşağında, Fransa'daki kraliyet yönetimi sona ermiştir ve İngiltere başta olmak üzere tüm Avrupa kentlerinde, yaşamı tümüyle dönüştürecek yeni bir dalga belirmektedir: Endüstrileşme hareketi. Kırsal bölgeleri terk ederek şehre yerleșen insanlar, sehir hayatına tam anlamıyla dahil olmayı ve vatandașlıkta eșit haklara sahip olmayı istemekte gecikmeyecektir. Bir yüzyıl önce tiyatro mekânlarında söz sahibi olmak için burjuvazinin verdiği mücadele, şimdi de şehre yeni gelenlerin mücadelesi olmuştur. Bu kez eski düzeni sürdürmek isteyen cephede aristokrasi değil, burjuvazi yer almaktadır; zira aristokrasinin denetiminde ișleyen bir tiyatro mekânı yoktur artık (Davis ve Holland, 2007; Bloemendal vd., 2008).

Önceki yüzyılda temelleri atılan melodram tarzı, sehrin yeni sakinlerini tatmin edecek yeni ifadeler kazanır. Rousseau'nun yücelttiği "vahşi ama özünde asil ve erdemli insan karakteri" bu dönemin edebiyat ve tiyatro eserlerine dam- 
gasını vurur. Immanuel Kant ve onun izindeki 19. yüzyıl düşünürleri, insan aklına ve özgür iradesine büyük görevler biçmektedir. Tüm insanlar eşit haklara sahip olmalıdır; kötülük, bu eşitlik hakkına karşı çıkmakla eş tutulur. Erdemli ve iyi insan, er geç ödülünü kazanacaktır; kötülügün nihaî olarak galip gelmesi asla mümkün olmayacaktır (Kadler, 1969, s. 69-126; Wiles, 2014, s. 111-186). Bu görüşler, matbaa teknolojisinin de gelişmesi sayesinde, gazete ve romanlar yoluyla modern şehir anlatısına işlenir. Bu bakış açısının tiyatrodaki ifadelerinde, aklı ve iradesiyle her türlü zorluğa karşı durarak erdemli olmaya çalışan sıradan kişilerin kahramanlık hikâyeleri izlenir (Pearson, 2015; Charnow, 2005).

Tiyatronun Avrupa topraklarında yaşadığı dönüşümler, bu yüzyıldan itibaren okyanusun diğer yakasını, Kuzey Amerika şehirlerini de kapsayacak şekilde düşünülmelidir. Zira Kuzey Amerika'da yeni yeni oluşmaya başlayan kentlerde, gösterinin ve seyirliklerin her biçimine karşı büyük bir merak ve iștah söz konusudur (Brown, 2015; Saxon, 2011).

Bu dönemde tiyatro mekânlarının teknolojik imkânlarında çarpıcı gelişmeler olmuştur. Her şeyden önce, eskiden sadece mumla aydınlatılabilen, daha sonra gaz lambalarına kavuşan tiyatro salonları, artık elektrikle aydınlatılabilmektedir. Sahnedeki dramatizasyon için kullanılan mekanizmalar, görsel ve ișitsel efektler, dönemin en kârlı keșif alanlarından birini olușturur. Öyle ki, tiyatro metninin içeriği ve biçimi, oyunculuğun kalitesi giderek en önemsiz unsur haline gelir. Böyle bir ortamda, düşüncelerini ciddiye alan hiçbir yazar tiyatro oyunları yazmayı aklına getirmez. (McCormick, 1993; Worrall, 2007) Yazara ödenen telif hakkı da giderek azaldığından, bu dönemdeki tiyatro gösterilerinin büyük bölümü, klişe bir hikâyenin eğlence ve duygu boşalımına yönelik müzikli, danslı, şaşırtmacalı birer sunumundan ibarettir. Bu dönemde en çok sayıda seyirci sirk ve vodvil gösterilerine gittiği için, bazı gösteri salonları sadece ve özellikle sirk gösterileri için inşa edilir (Shimko, 2012).

\section{Tiyatrodan Sinemaya Yeni Yüzyıl...}

Ancak teknolojik gelişimin tiyatro mekânlarında yarattığı asıl dönüşüm, o günün seyircileri için hiç beklemedikleri bir yönden gelir: Hareketin kaydedilmesine olanak sağlayan, filmin toplu olarak izlenmesini de mümkün kılan projeksiyon mekanizmasıdır bu.

28 Aralık 1895'te Lumière kardeşlerin Paris Grand Café'de gerçekleştirdiği ilk film gösterisinden itibaren sinema, teknolojinin tüm yeniliklerini seferber ederek, tiyatro salonlarındaki tüm gösterilerden daha fazla seyirci çeken bir ilgi odağı haline gelir. Toplu bir izleme mekânının bulunabildiği her şehirde artık bir sinema olgusu da vardır (Nowell-Smith, 1996, s. 7-61).

20. yüzyıl başında sinema, anlatım olanakları açısından tiyatroyla boy ölçüşebilecek bir olgunlukta değildir elbette. Ancak şu da bir gerçektir ki, sinema, binlerce senede oluşmuş tiyatro kültürünü ve bilgisini, teknolojik imkânların sınırlarını zorlayan bir yaratıcıı̆̆ı da devreye sokarak kullanacaktır. Seyirci, toplu bir seyirliği nasıl izleye- ceğini tiyatroda öğrenmiștir. Film kamerası ve montaj teknikleriyle anlatılacak olan her seyirlikte de, tiyatroda edinilmiş tüm anlatım olanakları kullanılacaktır (Butsch, 2008).

Klâsik tiyatro, 19. yüzyılda burjuvazinin kendini diğer sınıflardan ayırmak üzere kullandığı ve kendine mal ettiği küçük bir alana dönüşmüştür. Bu ortamda kendine yer bulamayan tüm seyircileri kucaklayan sinema ise eskiden tiyatronun üstlendiği önemli sosyal ișlevleri devralacaktır (Hansen, 1991). Endüstriyel kapitalist toplumun çocuğu sinema, teknolojideki her türlü yeniliği kendine mal etmeye yatkındır. Başlangıçta popüler kahvehanelerde, müzikhollerde gerçekleşen film gösterimleri, çok geçmeden izleyiciden bilet ücreti isteyebilecek özel mekânlara tașınır. 1914'te New York'ta açılan üç bin kișilik Strand tiyatrosu, sadece film gösterimleri için inşa edilen, amfitiyatro biçiminde büyük bir mekândır. "Film Sarayı" olarak isimlendiren bu konforlu salon büyük bir ilgiyle karşılanır ve sonraki iki sene içinde sadece Amerika'da 21 bin "film sarayı" açılır (Welling, 2007, s. 1-99).

Figür 10. 1918'de Pittsburgh'daki bir tiyatro salonunun dönüștürülmesiyle kullanıma açılan iki bin kișilik Warner sinema salonu. 1983 yılına kadar sinema salonu olarak kalan mekân, 1983 'te yıkılacak ve yerine Warner Center alışveriş merkezi açılacaktır. (Kaynak:https://lancasteronline.com/features/ entertainment/unscripted-an-unforgettable-trip-to-a-movie-palace/ article_420c1fd8-6585-11e6-8175-273da3500435.html)

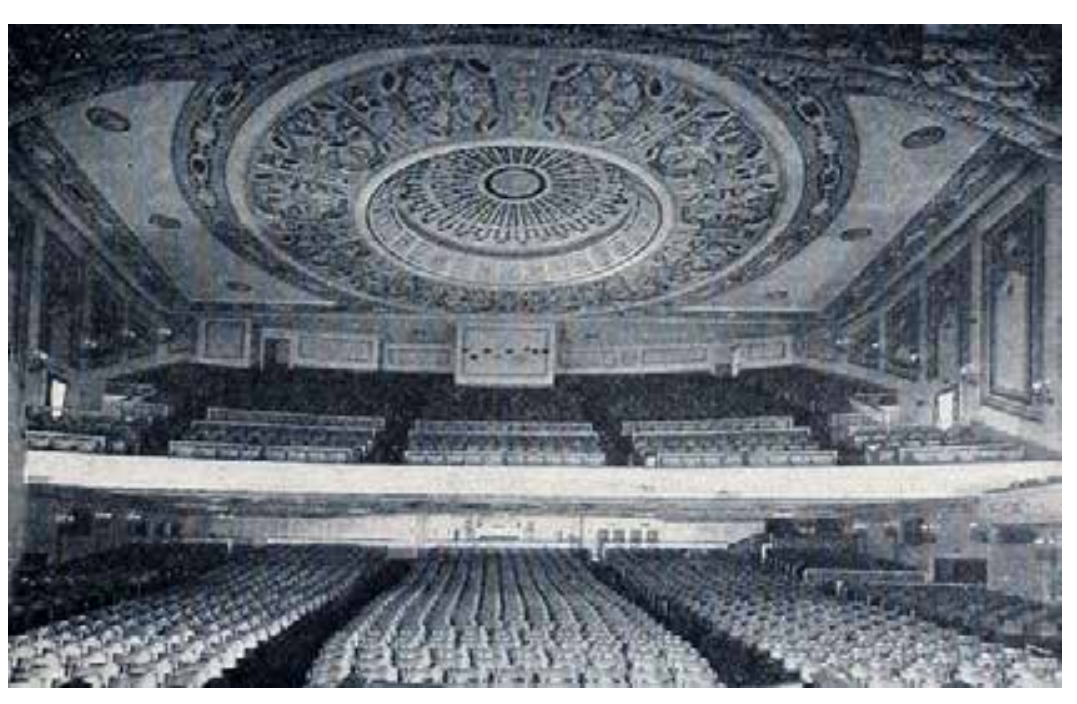

Bu dönemde tüm dünyadaki büyük kentlerde aynı durumu izlemek mümkündür. İstanbul'da halka açık ilk film gösterimi, 1897'de Sponeck Birahanesi'nde gerçekleşmiştir. Burada, Lumière kardeşlerin Paris Grand Café'de gösterdiği kısa filmler, aynı sırayla gösterilmiştir. Daha sonra film gösterileri çeşitli mekânlarda devam eder. 1908'de ilk sabit sinema salonu olarak bilinen Pathé Sineması açlır. 1915 
yılına kadar İstanbul'da yaklaşık yirmi sinema salonu açılmıștır ve bu sayı, sonraki yıllarda hızla artmaya devam edecektir (Bulunmaz ve Osmanoğlu, 2016, s. 16-39).

1915'ten önceki sinema salonlarında, birbirinden bağımsız kısa filmler; canIı müzik performansları, dansçı ve komedyen gösterileri ile birlikte seyredilir. Ancak bu tarihten sonra, sinemada klâsik dönem olarak bilinen ve 1950'lerin sonuna kadar sürecek olan Amerikan stüdyo sistemi dönemi başlar. Izleyici sinemada, karanlık ve kalabalık bir salonda, sessiz bir şekilde perdeye odaklanarak, birkaç saat süren kurgusal bir anlatı izlemektedir artık (Hall ve Neale, 2010).

Bir filmin kopyalanarak sınırsız sayıda çoğaltılma imkânı ve film çekimlerinin yüksek bütçelere ihtiyaç duyması, çok geçmeden film prodüksiyonunun tekelleşmesine ve Amerikan stüdyolarının olağanüstü güç merkezleri haline gelmesine yol açar. Film salonlarının, bilet parasını ödeyebilen herkese eşit bir katılım ortamı sunmasındaki "demokratik" imkânı gölgeleyen, hatta tersine çeviren bir durumdur bu (Belton, 2012).

Figür 11-12. "Dünyanın en büyük sineması" olarak lanse edilen altı bin kişilik Gaumont Palace, Paris'teki Hippodrome Tiyatrosu'nun sinema salonuna dönüştürülmesiyle, 14 Aralık 1907'de açılmıştı. 1972'de yıkılarak yerine otel inșa edildi. (Kaynak: https://commons. wikimedia.org/wiki/File:Paris___Gaumont_Palace_-_1912-1.jpg)

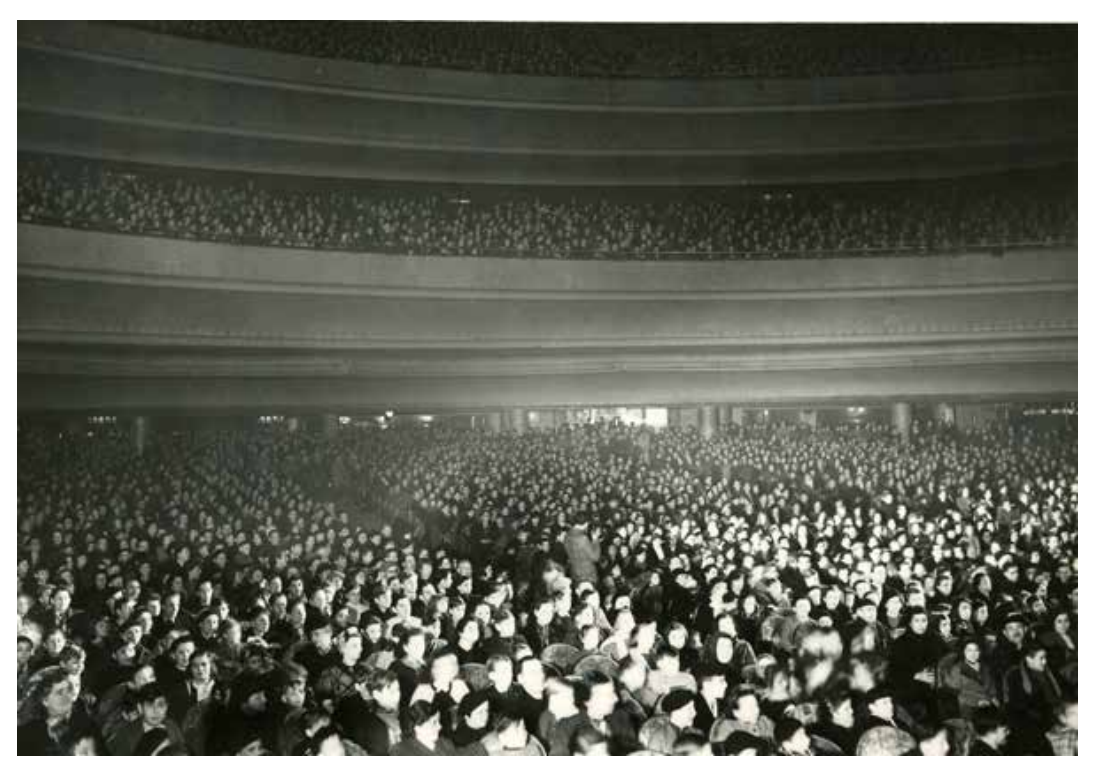

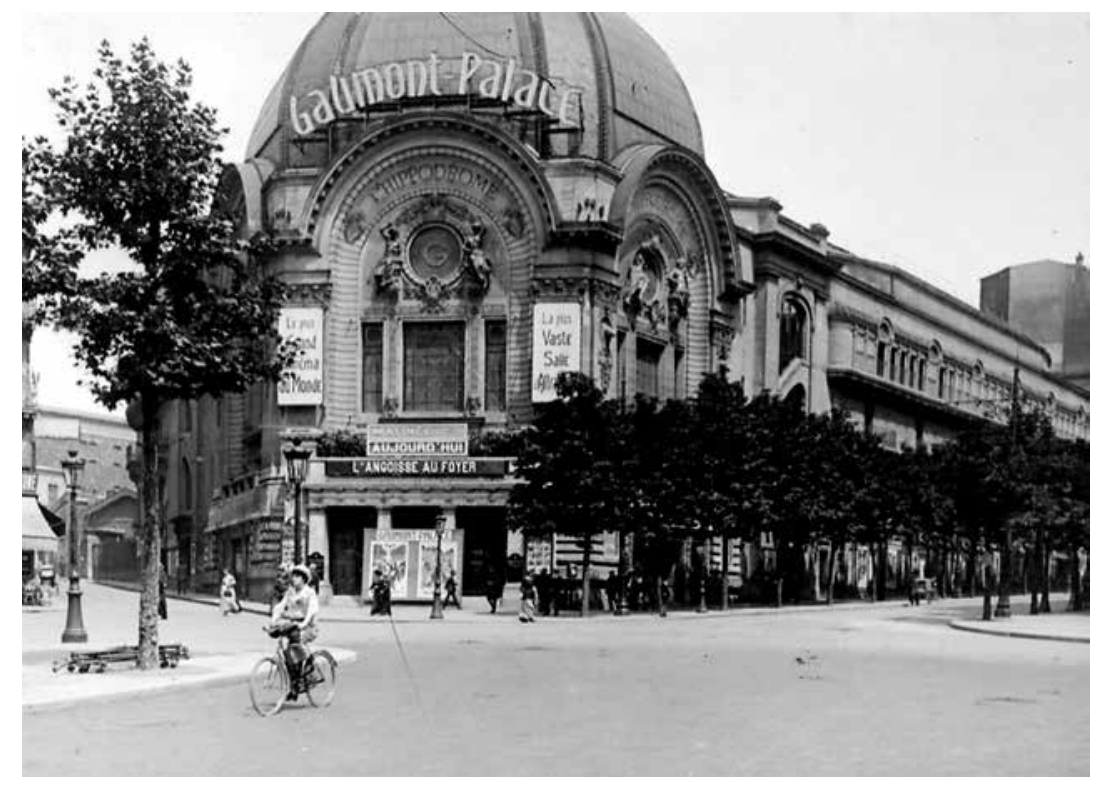

Stüdyo sistemiyle birlikte yerleşen koşullarda, tüm dünyadaki sinema izleyicileri, Amerikan film endüstrisinin üretim bandından çıkan filmleri izlemekte ve kapitalist tüketimi sürdürecek olan değerleri hayranlıkla özümsemektedir. Bu filmlerde izlenen hayatlar, üstün ve özenilecek standartlar olarak kabul edilir. Bu tüketim çarkına dahil olmak üzere çalıșlacak, konusulacak ve ilișki kurulacaktır. İki dünya savaşından sonra Amerikan ekonomisinin olağanüstü güç kazanması, hem stüdyo sisteminin daha da güçlenmesine, hem de bu filmlerde yüceltilen değerlerin tek kurtuluş vaadi olarak benimsenmesine yol açar. Dünya savașlarından sonra çöken karanlık ve yoksulluktan sıyrılmak isteyen insanların önündeki kırmızı elma, Amerikan rüyasının güzelce parlatılarak sunulduğu iştah uyandırıcı, baştan çıkarıcı filmlerdir.

Sinemanın bu dönemde hayatın içindeki yerini anlamak için, bazı rakamlara bakmak yeterlidir: 1920'lerin sonunda, sadece Amerika'da haftada 80 milyon sinema bileti satılmaktadır. 1940'lara gelindiğinde, her büyük sehirde bes bin kişilik çok sayıda sinema salonu mevcuttur. Beş film stüdyosu (MGM, Paramount, RKO, Warner Bros, Twentieth Century Fox) Amerika'daki binlerce sinema salonunun işletmesini zincir olarak tekelinde bulundurur. Ancak daha önemlisi, bu salonlarda izlenen filmlerin aynı anda tüm dünyadaki şehir ve kasabalarda da izlenmekte oluşudur. Zira bu filmlerin gösterimi için tek gereken, bir film projektörü ve bir film perdesi içeren geniş bir mekândır. Sıcak iklimlerde bu mekân, duvarı ve çatısı dahi olmayan büyükçe bir alan olabilir. Yazlık ve kışlık sinemalar, şehir hayatının en sevilen toplanma mekânlarıdır (Welling, 2007). 
Figür 13. 1927'de New York'ta açlan Warners' Theatre. Illk sesli film The Jazz Singer'ın ilk toplu gösterimi (1927) burada yapılmıştı. (Kaynak: http://www.boweryboyshistory.com/2009/10/all-that-jazzcinema-history-on.html)

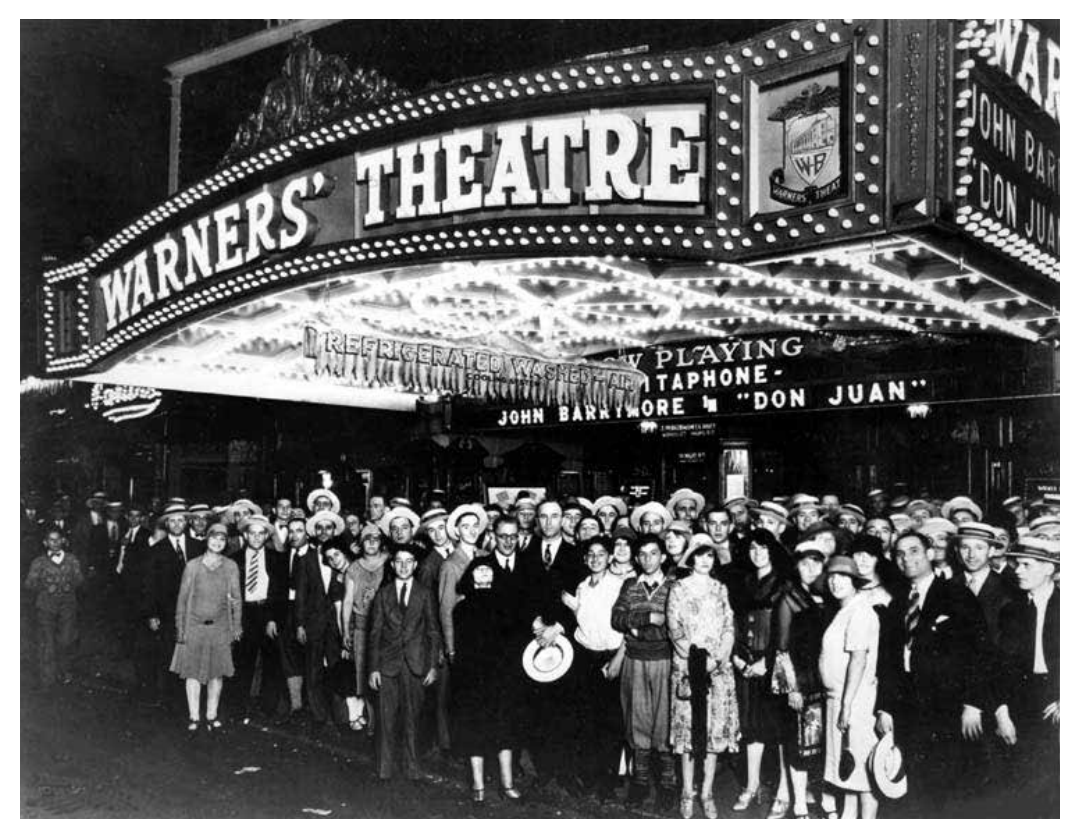

Seyircinin bilet için gözden çıkarabildiği ücret, salonun konfor düzeyini bire bir yansıtacaktır. Kadife koltuklar, kristal avizeler ve baş döndürücü hoş kokular içinde izlenen bir film, aynı anda başka bir salonda buz gibi tahta sandalyeler üstünde, havasız, tozlu, sıkışık bir ortamda da izlenebilir. Sinema mekânları boyut, konfor, dekor, atmosfer, teknik imkânlar, işletme ve bilet ücretleri açısından olağanüstü bir çeşitlilik gösterir; ancak şu bir gerçektir ki hepsi, seyirciye o sırada ait olduğu sosyal çevreyi ve buradaki kendi yerini bedensel, zihinsel ve duygusal olarak tecrübe ettirmektedir.

Kapitalist tüketim kültürünün sinemayla birlikte tarihsel gelişimi, sinema mekânlarının şehirde yerleştiği konumlar üzerinden de izlenebilir. Film gösterimleri için ilk yıllarda alışveriş bölgelerindeki dükkânlar arasına sıkıșmıs mekânlar kullanılmıștır. Daha sonra inşa edilen "film sarayı" formundaki teatral binalar, şehrin en nüfuzlu, en ışıklı bölgelerine yerleşir. Amerika'da 1940'lardan itibaren çok sayıda mağazayı içinde toplayan, birkaç katlı, "eğlence için alışveriş" arzusunun propagandasını yapan alışveriş merkezleri açılacaktır. Her alısveriș merkezinin içinde ya da yanında, aynı tarzda inșa edilen bir ya da birkaç sinema salonu bulunur. (Welling, 2007, s. 251-265). Film izlemek, alışveriş yapma ritüelinin ve eğlencesinin bir uzantısıdır. Filmlerin beslediği fantezi dünyası alıșveriș ve tüketimi arttıracak, alışveriş yapmanın insanı tatmin etmediği noktada film izlemeye koşulacaktır. Bu etkileşim, dünya sahnesinde görünür olmanın, ancak alışveriş yapmakla mümkün olduğu yönünde bir yanılsama oluşturacaktır.
Figür 14. New York'taki Kings Theatre. Bugün çok amaçlı bir gösteri merkezi olarak kullanılan salon, 7 Eylül 1929'da yaklaşık dört bin kişilik bir "film sarayı" olarak açılmıştı. (Kaynak: https://www. newyorklatinculture.com/kings-theatre/)

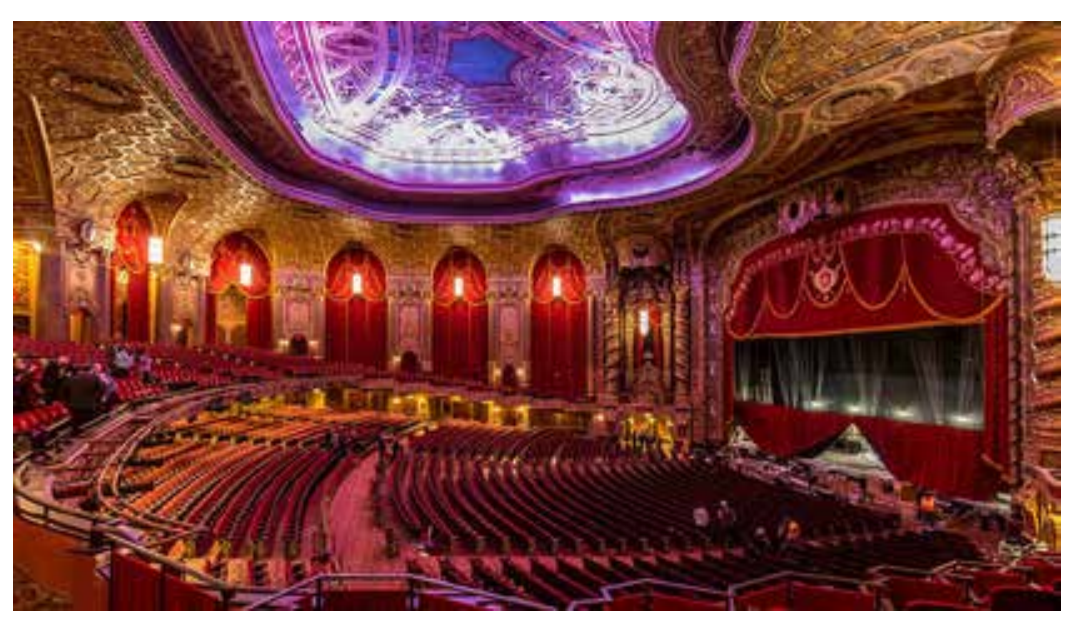

Figür 15. 1931'de bir "film sarayı" olarak açılan Oakland'daki Paramount Theatre bugün, aslına uygun bir tarzda restore edilmekle birlikte, teknolojik yeniliklerin üst düzeyde kullanıldığ bir gösteri merkezi. (Kaynak: https://www.oaklandgrown.org/ paramount-theatre-of-the-arts/)

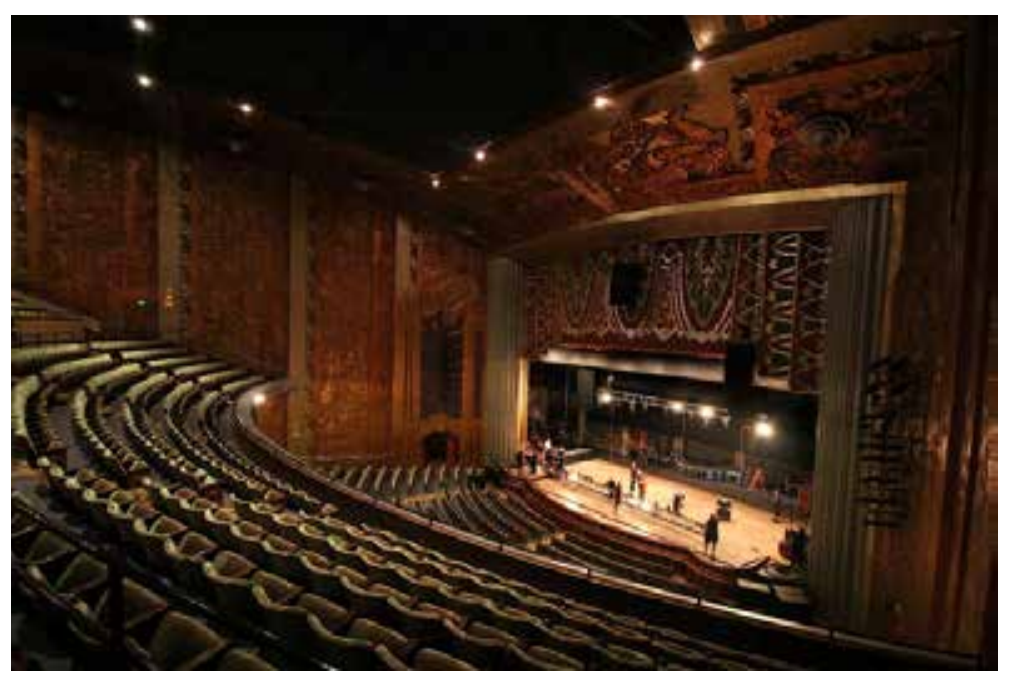

Toplu hayatın merkezinde yer alan "alışveriş artı sinema" ritüeli, 1950'lerde televizyonun ortaya çıkmasıyla eski popülaritesini yitirmiş görünür. 1970'lerde vi- 
deo kasetçaların piyasaya sunulması da bu eğilimi arttıracak gibidir (Butsch, 2000). Ancak bu koşullarda, ilk anda öngörülemeyen bir gelişme olacaktır: Televizyon ve video kaset, sinema tarihinde çekilmiş tüm filmlere erişim sağladığı için, film izleme tutkusu hafiflemek bir yana, daha baskın bir hale gelir (Rosenbaum, 2010). Bu durumda, seyirciyi evinin konforundan, sinema salonuna çekecek olan nedir?

Figür 16. Singapur'daki Golden Village VivoCity Multiplex. 22.4 metre genişliğinde bir GV Max sinema perdesi. Aynı binada onbeş farklı sinema salonunda film gösterimi yapılıyor. (Kaynak: https:// www.thebestsingapore.com/best-place/golden-village-vivocity/)

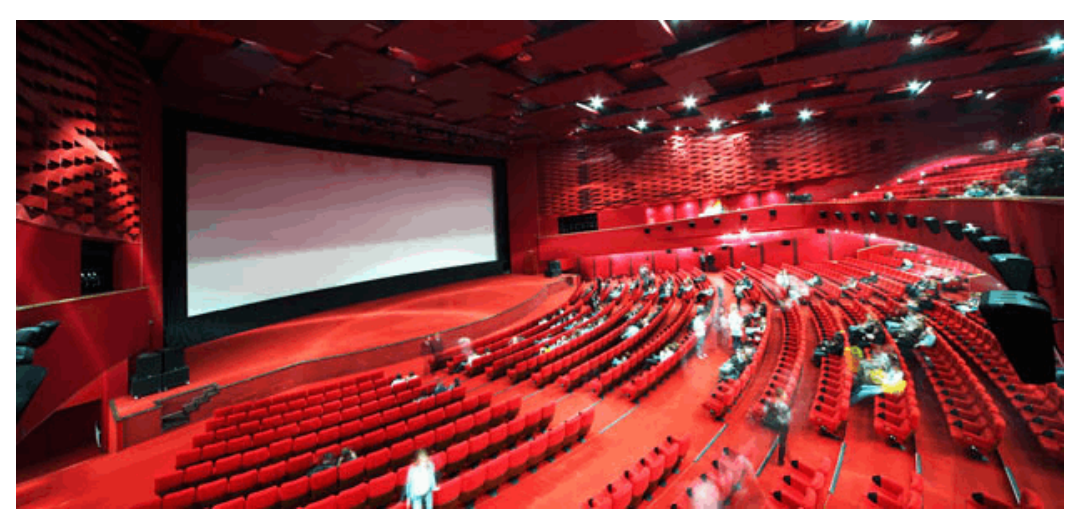

Bu sorunun yanıtı birkaç yönde bulunabilir. Öncelikle, sinema salonlarındaki ses ve görüntü teknolojisi, film yapımında kullanılan olanaklarla birlikte, sürekli gelişmektedir. Bu olanaklarla çekilen bir filmi izlemek için ev ortamı, elbette sinema salonuyla boy ölçüşemez (Hall ve Neale, 2010, s. 235-264). İkincisi ve daha önemlisi, film izleme deneyimini yüzlerce kişiyle beraber yaşamak, aynı filmi evde izlemekten çok daha farklı ve zengin bir deneyimdir. Duyuları ve duyguları maksimum derecede harekete geçirmek üzere çekilmiş bir filmi, benzer duyular ve duygularla dolu insanlarla bir arada deneyimlemek, insanın paylaşma ve beraberlik ihtiyacını üst düzeyde tatmin eder. Bu intiyacın yarattığı ilginç bir oluşum da, özellikle büyük şehirlerde, eğitimli ve kültürel sermayesi yüksek kesimlerin buluştuğu yerlerde açılan "sinematek" benzeri sinema kulüpleridir. Burada, "ticari" olarak nitelenen filmlere karşı durarak çekilmiş filmler izlenir, konuşulur, tartışılır (Belton, 2012, s.364-385).

Bu çizgideki başka bir önemli oluşum da, film festivalleridir. Bugün dünyanın tüm büyük şehirlerinde yılda en az bir, genellikle çok daha fazla film festivali düzenlenmektedir. Bu festivallerin en geniş bütçeli olanları, şehirden şehre gezen bir "festival halkı" oluşturmuştur (Wong, 2011). Bunların dışında, özellikle tek bir tema ya da film türü üzerine odaklanan çok sayıda film festivali düzenlenir. Bu festivaller, aynı konu ve meraklar çevresinde toplanan yüzlerce insanı bir araya getiren, tanıştıran, konuşturan ve birlik duygusu sağlayan canlı ve enerjik birer ritüeldir. Bu ritüeller de kent mekânlarına yayılarak modern gösterinin bileșenlerinden birine dönüşür.
Figür 17. Üsküp'te her yıl düzenlenen MakeDox Belgesel Film Festivali. Gösterimler, fotoğrafta görülen Kurşunlu Han'da yapılıyor. (Kaynak: https://contestwatchers.com/makedox-creativedocumentary-film-festival-2014//

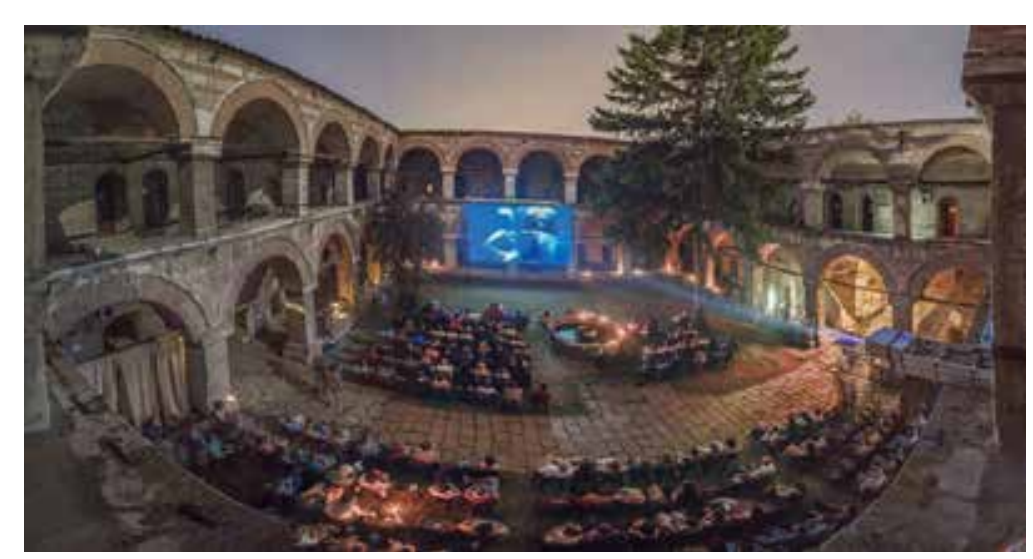

Figür 18-19. M.S. 1.Yüzyıl'da inşa edilen 26 bin kişilik Pula Amfitiyatrosu (Hırvatistan). Bu amfitiyatro bugün toplu etkinlikler için, film gösterimleri için kullanılıyor. (Kaynak: https:// www.touropia.com/roman-amphitheaters/ ve https://www. boredpanda.com/arena-pula croatia/?utm_source=google\&utm_ medium=organic\&utm_campaign=organic

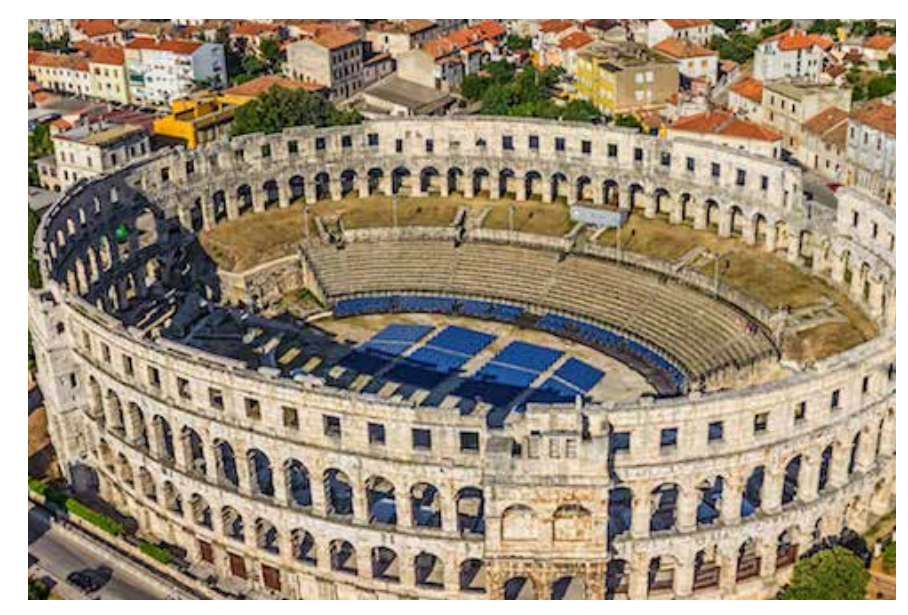




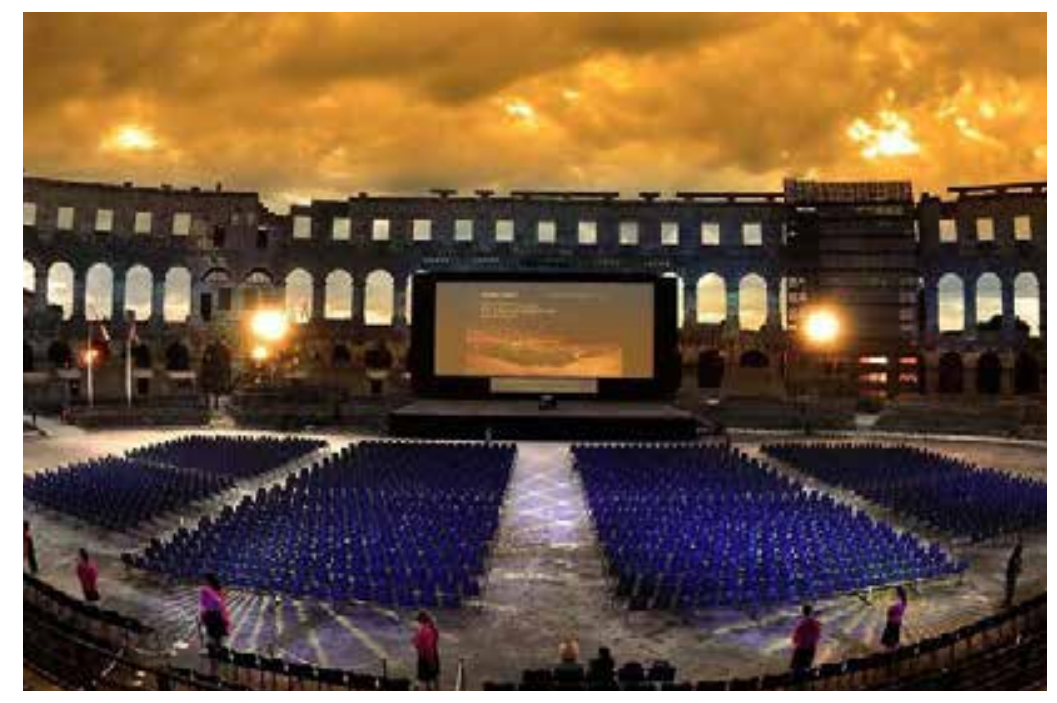

\section{Gösteriselleșmek ve Ötesi..}

“Bütün dünya bir sahnedir,

İçindeki tüm erkekler ve kadınlar da birer oyuncu..."

Bu satırlar, William Shakespeare imzalı "As You Like It" (Size Nasıl Geliyorsa) oyununun en tanınmış dizeleri (Shakespeare, 2006, s. 227).

Dünyanın bir sahne, üzerindeki yașantının da bir gösteri olduğu düșüncesi hiç yeni bir fikir değil; bu bakış açısı antik çağlardan bu yana devam eden bir düşüncenin izlerini taşıyor. İnsanlık tarihinin en eski sanatlarından olan seyirlik anlatı sanatı, yüzyıllar boyunca incelerek, gelişerek, derinleşerek her insanın özümsediği, içselleştirdiği bir dil oluşturmuş durumda. Fiziksel bir mekân olarak amfitiyatro, içerdiği sosyal ve siyasî iliş̧kilerle bu dilin oluşmasına her dönemde zemin oluşturdu.

21. yüzyılda dünyanın çok hızlı bir dijitalleşme süreciyle bir "ağ toplumu" haline gelmiş olması, bu dilin her türlü ilişkiye sirayet etmesini kolaylaştırdı ve onu fiziksel mekândan neredeyse bağımsız bir hale getirdi. Bir önceki yüzyılda teşhisi konmuș olan "gösteriselleșme" sendromu, daha da derinleşerek yayılmış gibi görünüyor. Görsel imgelerin çokluğu ve dolaşım hızı, insanda bir sürüklenme ve uyuşma haline yol açabiliyor. Tüketimi ve maddî varlığı yücelten hayat görüşü, "izleniyorum, o halde varım" yanılsamasını derinleştiriyor. Bu yanılsama içindeki kişi, kendi düşüncelerinin etkisini ve seçim özgürlüğünü fark edemez durumda.

Bu gösteriselleşme halinde insan, tüketilmek üzere karşısına çıkan imgeleri taklit etmekle yetiniyor. Her an yaptığı seçimlerin, düșüncelerinin ve eylemlerinin etkisini hiç hesaba almıyor. Seçim özgürlüğünün sorumluluğunu üstlenmiyor.
Hayatındaki neden-sonuç ilişkiselliğini gözetemediği bir duruma düşüyor.

Oysa, deneyimsel bilginin her dönemde işaret ettiği üzere, her insan bir mikrokozmostur. Bu mikrokozmosta hem izlenen, hem de izleyici konumundadır. Hayatı, bu dünya sahnesinde an be an oynadığı rollerle sınırlı değildir; yaşam deneyimi, ömrü boyunca yaptığı bilinçli seçimlerin toplamıyla oluşur. İnsan böylece kendi seçimlerinin deneyimiyle oluşurken, dünyayı da dönüştürür. Evet; dünya bir sahnedir, ancak üzerindeki oyunun anlamlı ve değerli olması için, oynadığımız rollerin sorumluluğunu üstlenmemiz de gerekmektedir.

\section{Kaynakça}

Adrados, F. R. (2017). Cult, lyric and komos: The origins of tragedy and comedy, once again. (S Fountoulakis, A., Markantonatos, A., Vasilaros, G., ve Xanthake-Karamanou, (Ed.) G. Theatre world: Critical perspectives on Greek tragedy and comedy içinde (s. 3-14). Berlin: De Gruyter.

Arnold, C. (2015). Globe: Life in Shakespeare's London. London: Simon \& Schuster.

Arnott, P. D. (2003). Public and performance in the Greek theatre. London: Routledge.

Auchincloss, L. (1996). La gloire: The Roman Empire of Corneille and Racine. Columbia, SC: University of South Carolina Press.

Beacham, R. C. (1991). The Roman theatre and its audience. Cambridge, MA: Harvard University Press.

Beacham, R. C. (2007). Playing places: The temporary and the permanent. McDonald, M. ve Walton, J. M. (Ed.). The Cambridge companion to Greek and Roman theatre içinde (s. 202-226). Cambridge: Cambridge University Press.

Belton, J. (2012). American cinema/American culture. New York: McGraw-Hill.

Bernheimer, R. (1956). Theatrum Mundi. The Art Bulletin, 38(4), s. 225.-247. doi:10.2307/3047670.

Bloemendal, J., Eversmann, P. G. F. ve Strietman E. (2008). Drama, performance and debate: Theatre and public opinion in the early modern period. Leiden: Brill.

Bomgardner, D. L. (2001). The story of the Roman amphitheatre. London: Taylor and Francis.

Bonnard, A. (1962). Greek civilization: From the lliad to the Parthenon. (L. Sells, Çev.). New York, NY: Macmillan Press.

Brown, J. (1995). The theatre in America during the revolution. Cambridge: Cambridge University Press.

Bulunmaz, B. ve Osmanoğlu, Ö. (2016). İstanbul'un 100 sinema salonu. İstanbul: 
İstanbul Büyükşehir Belediyesi Yayınları.

Butsch, R. (2000). The making of American audiences: From stage to television, 1750-1990. Cambridge: Cambridge University Press.

Butsch, R. (2008). The citizen audience: Crowds, publics, and individuals. New York: Routledge.

Carles, N. R. (2016). Early modern diplomacy, theatre and soft power: The making of peace. London: Palgrave Macmillan.

Charnow, S. D. (2005). Theatre, politics, and markets in fin-de-siècle Paris: Staging modernity. Basingstoke: Palgrave Macmillan.

Cordner, M. (2007). Players, playwrights, playhouses: Investigating performance, 1660-1800. Basingstoke: Palgrave Macmillan.

Csapo, E., Goette H. R., Green J. R. ve Wilson P. (Ed.). Greek Theatre in the fourth century BC. (2014). Berlin: Walter de Gruyter.

Davis T. C. ve Holland P. (2007). The performing century: Nineteenth-century theatre's history. Basingstoke Palgrave Macmillan.

Debord, G. (1994). The society of the spectacle. (D. Nicholson-Smith, Çev.). New York, NY: Zone Books.

Egginton, W. (2003). How the world became a stage: Presence, theatricality, and the question of modernity. Albany, NY: State University of New York Press.

Fischer-Lichte, E. (2002). History of European drama and theatre. London: Routledge.

Fitzpatrick, T. (2011). Playwright, space and place in early modern performance: Shakespeare and Company. London: Routledge.

Graf, F. (2015). Roman festivals in the Greek East from the early empire to the Middle Byzantine Era. Cambridge: Cambridge University Press.

Greenberg, M. (1992). Subjectivity and subjugation in seventeenth-century drama and prose. Cambridge University Press.

Greenberg, M. (2010). Racine: From ancient myth to tragic modernity. Minneapolis: University of Minnesota Press.

Greenblatt, S. (2014). Will in the world: How Shakespeare became Shakespeare. London: The Bodley Head.

Hall, E. (2006). The theatrical cast of Athens. Oxford: Oxford University Press.

Hall, S. ve Neale, S. (2010). Epics, spectacles, and blockbusters: A Hollywood history. Detroit, MI: Wayne State University Press.

Hansen, M. B. (1991). Babel and Babylon: Spectatorship in American silent film. Cambridge, MA, etc.: Harvard University Press.
Jondorf, G. (1990). French Renaissance tragedy: The dramatic word. Cambridge: Cambridge University Press.

Kadler, E. H. (1969). Literary figures in French drama 1784-1834. Den Haag: Nijhoff.

Leggatt, A. (1992). Jacobean public theatre. London: Routledge.

Lopez, J. (2003). Theatrical convention and audience response in early modern drama. Cambridge: Cambridge University Press.

Low J. A. ve Myhill N. (2011). Imagining the audience in early modern drama 1558-1642. New York, NY: Palgrave Macmillan.

Manuwald, G. (2011). Roman republican theatre. Cambridge: Cambridge University Press.

Marshall, C. W. (2006). The stagecraft and performance of Roman comedy. Cambridge: Cambridge University Press.

McCormick, J. (1993). Popular theatres of nineteenth-century France. London: Routledge.

McDonald, M. ve Walton, J. M. (Ed.). (2015). The Cambridge companion to Greek and Roman theatre. Cambridge: Cambridge University Press.

Moretti, J. C. (2014). The evolution of theatre architecture outside Athens in the fourth century. Csapo, E., Goette H. R., Green J. R. ve Wilson P. (Ed.). Greek theatre in the fourth century BC. Içinde (s. 107-140). Berlin: Walter de Gruyter.

Mortensen, L. B., Lehtonen, T. M. ve Bergholm, A. (2013). The performance of Christian and pagan storyworlds: Non-canonical chapters of the history of Nordic medieval literature. Turnhout: Brepols.

Nowell-Smith, G. (1997). The Oxford history of world cinema. Oxford: Oxford University Press.

Oates, W. J. ve O'Neill E. Jr. (1938). The complete Greek drama; All the extant tragedies of Aeschylus, Sophocles and Euripides, and the comedies of Aristophanes and Menander. New York, NY: Random House.

Pearson, R. (2015). Victorian writers and the stage: The plays of Dickens, Browning, Collins and Tennyson. Houndmills, Basingstoke, Hampshire: Palgrave Macmillan.

Postlewate, L. ve Hüsken, W. N. (2007). Acts and texts: Performance and ritual in the Middle Ages and the Renaissance. Amsterdam: Rodopi.

Powers, M. (2014). Athenian tragedy in performance. lowa City: University of lowa Press.

Prest, J. (2014). Controversy in French drama: Moliere's Tartuffe and the struggle for influence. New York, NY: Palgrave Macmillan. 
Rehm, R. (2005). Greek tragic theatre. London: Routledge.

Roselli, D. K. (2011). Theater of the people: Spectators and society in ancient Athens. Austin: University of Texas Press.

Rosenbaum, J. (2010). Goodbye cinema, hello cinephilia: Film culture in transition. Chicago: The University of Chicago Press.

Scherb, V. I. (2001). Staging faith: East Anglian drama in the later Middle Ages. Madison: Fairleigh Dickinson University Press.

Scullard, H. H. (1981). Festivals and ceremonies of the Roman Republic. London: Thames and Hudson.

Sear, F. (2006). Roman theatres: An architectural study. Oxford: Oxford University Press.

Shakespeare, W. ve Dusinberre, J. (2006). The Arden Shakespeare: As You Like It. London: AS.

Shimko, R. B. (2012). Public theatres and theatre publics. Newcastle upon Tyne: Cambridge Scholars.

Storey, I. C. ve Allan, A. (2005). A guide to ancient greek drama. Oxford: Wiley Blackwell.

Sturges, R. S. (2015). The circulation of power in Medieval Biblical drama: Theaters of authority. Basingstoke: Palgrave Macmillan.

Walton, J. M. (2015). Greek sense of theatre: Tragedy and comedy. London: Routledge.

Welling, D. (2007). Cinema Houston: From nickelodeon to megaplex. Austin: University of Texas Press.

Wickham, G. (1992). A history of the theatre. London: Phaidon Press.

Wiles, D. (1997). Tragedy in Athens: Performance space and theatrical meaning. Cambridge: Cambridge University Press.

Wiles, D. (2000). Greek theatre performance: An introduction. Cambridge: Cambridge University Press.

Wiles, D. (2014). Theatre and citizenship: The history of a practice. Cambridge: Cambridge University Press.

Wong, C. H. (2011). Film festivals culture, people, and power on the global screen. New Brunswick, NJ: Rutgers University Press.

Worrall, D. (2007). Politics of romantic theatricality 1787-1832: The road to the stage. Basingstoke: Palgrave Macmillan. 